\title{
Effects of endocannabinoid system modulation on cognitive and emotional behavior
}

\author{
Claudio Zanettini ${ }^{1}$, Leigh V. Panlilio ${ }^{1}$, Mano Aliczki ${ }^{2}$, Steven R. Goldberg ${ }^{1}$, József Haller ${ }^{2}$ and Sevil Yasar ${ }^{3}$ * \\ Department of Health and Human Services, Preclinical Pharmacology Section, Behavioral Neurosciences Branch, Intramural Research Program, National Institute \\ on Drug Abuse, National Institutes of Health, Baltimore, MD, USA \\ ${ }^{2}$ Department of Behavioral Neurobiology, Institute of Experimental Medicine, Budapest, Hungary \\ ${ }^{3}$ Division of Geriatric Medicine and Gerontology, Johns Hopkins University School of Medicine, Baltimore, MD, USA
}

Edited by:

Viviana Trezza, University Roma Tre, Italy

Reviewed by:

Viviana Trezza, University Roma Tre, Italy

Patrizia Campolongo, Università degli

Studi di Roma La Sapienza, Italy

*Correspondence:

Sevil Yasar, Division of Geriatric

Medicine and Gerontology,

Department of Medicine, Johns

Hopkins School of Medicine, 5505

Hopkins Bayview Circle, Baltimore,

MD 21224, USA.

e-mail: syasar@jhmi.edu
Cannabis has long been known to produce cognitive and emotional effects. Research has shown that cannabinoid drugs produce these effects by driving the brain's endogenous cannabinoid system and that this system plays a modulatory role in many cognitive and emotional processes. This review focuses on the effects of endocannabinoid system modulation in animal models of cognition (learning and memory) and emotion (anxiety and depression). We review studies in which natural or synthetic cannabinoid agonists were administered to directly stimulate cannabinoid receptors or, conversely, where cannabinoid antagonists were administered to inhibit the activity of cannabinoid receptors. In addition, studies are reviewed that involved genetic disruption of cannabinoid receptors or genetic or pharmacological manipulation of the endocannabinoid-degrading enzyme, fatty acid amide hydrolase (FAAH). Endocannabinoids affect the function of many neurotransmitter systems, some of which play opposing roles. The diversity of cannabinoid roles and the complexity of task-dependent activation of neuronal circuits may lead to the effects of endocannabinoid system modulation being strongly dependent on environmental conditions. Recent findings are reviewed that raise the possibility that endocannabinoid signaling may change the impact of environmental influences on emotional and cognitive behavior rather than selectively affecting any specific behavior.

Keywords: endocannabinoids, cognition, anxiety, depression, learning, memory, animal models
Cannabis has been used by humans for millennia and has long been known to produce cognitive and emotional effects. Research over the past two decades has shown that cannabinoid drugs produce these effects by driving the brain's endogenous cannabinoid system, and that this system plays a modulatory role in many cognitive and emotional processes. This review will focus on the effects of endocannabinoid system modulation in animal models of cognition (learning and memory) and emotion (anxiety and depression).

This research has been facilitated by the availability of pharmacological tools that are used in four general ways:

(1) An exogenous cannabinoid agonist can be administered to directly stimulate cannabinoid receptors. Administering cannabinoid receptor agonists such as $\Delta^{9}$-THC (the main active constituent of cannabis) or WIN55212 (a synthetic agonist) can provide information about the effects of illicit cannabinoid use and also about the potential therapeutic or adverse effects of cannabinoid-related medications. Cannabinoid substances that occur endogenously, such as anandamide, can also be synthesized and administered exogenously to gain insight into their function.

(2) A cannabinoid receptor antagonist can be administered along with another treatment to determine whether effects of the treatment depend on its actions at cannabinoid receptors.
For example, if blocking cannabinoid $\mathrm{CB}_{1}$ receptors with an antagonist such as rimonabant prevents the treatment from having a certain effect, that effect of the treatment is said to be mediated by $\mathrm{CB}_{1}$ receptors.

(3) Ongoing endocannabinoid signaling can be blocked by administering a cannabinoid receptor antagonist alone. When endocannabinoid signaling is blocked, behaviors that are modulated by this signaling should increases or decrease, depending on whether the modulation is negative or positive. This approach assumes that the antagonist blocks endogenously released endocannabinoids, but does not otherwise affect signaling. Unfortunately, the antagonists that have been used most frequently for this purpose (rimonabant and AM251) also function as inverse agonists and may affect neuronal functions even in the absence of the release of endocannabinoid agonists.

(4) Endocannabinoid signaling can be enhanced by administering an enzyme inhibitor that prevents the breakdown of endocannabinoids that have been released. Endocannabinoids are synthesized "on demand" when synaptic neurotransmission surpasses a certain threshold. Treatments that prevent the breakdown of endocannabinoids should mainly affect cells in the immediate areas where an endocannabinoid is being released. In contrast, exogenous agonists affect synapses wherever the receptors are expressed. Thus, treatments that prevent 
endocannabinoid breakdown should magnify the ongoing effects of endocannabinoids and might provide better insight into normal function. Anandamide, the most frequently studied endocannabinoid, is degraded by the enzyme fatty acid amid hydrolase (FAAH). Inhibitors of FAAH first became available about 7 years ago (e.g., Tarzia et al., 2003; Mor et al., 2004), and there is now a large amount of information concerning the effects of FAAH inhibitors on cognitive and emotional behavior. Inhibitors of the degradation of 2-AG, the other major endocannabinoid that has been identified, have also been recently developed (e.g., Long et al., 2009), but information on their cognitive or emotional impact is too scarce to be reviewed at this time.

In addition to these four pharmacological approaches, the role of endocannabinoids in cognitive and emotional processes can be investigated with genetically modified strains of rodents. This has been accomplished in two general ways: deleting a specific cannabinoid receptor subtype (i.e., $\mathrm{CB}_{1}$ ), which excludes cannabinoid signaling; and deleting a metabolizing enzyme (i.e., FAAH), which enhances endogenous endocannabinoid signaling.

Each of these pharmacological and genetic approaches has advantages and disadvantages. For example, manipulating FAAH affects not only endocannabinoids but related fatty acids that bind at non-cannabinoid sites, such as peroxisome proliferatoractivated receptors and transient receptor-potential vanilloid receptors. When a receptor or enzyme is genetically deleted, other mechanisms may be affected by their absence. Therefore, the best understanding is gained through convergence, comparing the results obtained with different approaches.

\section{EFFECTS OF ENDOCANNABINOID SYSTEM MODULATION ON LEARNING AND MEMORY}

The memory-impairing effects of marijuana in humans have been widely recognized since at least the 1970s (Tart, 1970). Interest in the role played by endocannabinoids in cognitive processes has been stimulated by evidence that $\mathrm{CB}_{1}$ receptors are highly expressed (Herkenham et al., 1991) - and endocannabinoids (anandamide and 2-AG) occur in high concentrations (Di Marzo et al., 2000) - in the hippocampus, a brain area that plays a critical role in learning and memory. Animal models have been used extensively to assess the effects of cannabinoid manipulations on various stages of learning and memory, including acquisition, consolidation, and retrieval (Riedel and Davies, 2005; Varvel et al., 2009). Most of these studies have involved spatial learning. In general, the findings are that exogenous and endogenous cannabinoid agonists impair working memory and the acquisition of longterm memory, while cannabinoid antagonists/inverse agonists or genetic deletion of cannabinoid receptors are sometimes found to enhance learning and memory.

Endocannabinoid signaling can affect many behavioral and physiological processes, including locomotion, feeding, anxiety, reward, and nociception. Therefore, to confidently attribute the effects of cannabinoid manipulations to learning and memory processes per se, as opposed to motivational, emotional, or motor processes, it is important to consider complementary models. For example, some memory models involve aversive motivation (e.g., escape from a water-filled pool), while others involve appetitive motivation (e.g., food-reinforced behavior in delayed matching tasks); finding similar effects of a drug in both aversive and appetitive models would suggest an effect on memory rather than motivation. It can also be informative to test the effects of a treatment in both a memory model and a more general, non-cognitive behavioral assay, such as spontaneous locomotor activity in an open field. In the following sections, we will consider the findings obtained with specific models of long-term memory (see Effects of Endocannabinoid System Modulation on Learning and Memory) and working memory (see Working Memory).

\section{EFFECTS OF CANNABINOID CB 1 RECEPTOR AGONISTS AND ANTAGONISTS ON MEMORY ACOUISITION AND LONG-TERM MEMORY Water maze}

Much of the evidence that activating cannabinoid receptors can impair learning comes from studies using water maze procedures, which focus on spatial memory. In these tests the animals are trained to find a submerged platform in a tank filled with opaque water. Memory acquisition becomes evident over trials as successive reductions in the path length or the latency to reach the platform. In mice, acute systemic administration of $\Delta^{9}-\mathrm{THC}$ $(8 \mathrm{mg} / \mathrm{kg}, \mathrm{IP})$ before the training session disrupts acquisition in the water maze test without affecting locomotion; this effect is prevented by the $\mathrm{CB}_{1}$ antagonist/inverse agonist rimonabant (DaSilva and Takahashi, 2002). Deficits in place-learning have also been reported in rats treated repeatedly with $\Delta^{9}$-THC (Moore et al., 2010) or acutely with $\Delta^{8}$-THC (Diana et al., 2003) or synthetic $\mathrm{CB}_{1}$ agonists such as HU-210 (Ferrari et al., 1999), but not with the synthetic agonist nabilone (Diana et al., 2003). However, in these experiments, the effects of $\mathrm{CB}_{1}$-receptor blockade were not tested. Another synthetic cannabinoid, WIN55212-2 ( 1 and $3 \mathrm{mg} / \mathrm{kg}$ ), has been found to impair acquisition in the water maze, but his effect was not blocked by $\mathrm{CB}_{1}$ antagonists, suggesting WIN55212-2 may impair learning by more than one mechanism (Robinson et al., 2010).

Water maze procedures have also been used to study the effects of $\Delta^{9}$-THC on memory retrieval. For this purpose, rats that have already reached a criterion level of performance in the task are injected with the drug prior to a test session. Two laboratories have reported that - at doses known to impair memory acquisition $-\Delta^{9}$-THC did not impair memory retrieval in the water maze (Mishima et al., 2001; Varvel et al., 2001, 2007). These findings suggest that, once established, reference memory is not susceptible to modulation by cannabinoid compounds.

\section{Contextual fear conditioning}

$\mathrm{CB}_{1}$ agonists can also impair acquisition in another model of spatial memory, contextual fear conditioning. In this test, rodents are briefly exposed to footshock in a distinctive context, then tested by re-exposing them to the context. Immobility (freezing) during the test provides a measure of memory. The synthetic $\mathrm{CB}_{1}$ agonist WIN55212-2 (2.5 and $5.0 \mathrm{mg} / \mathrm{kg})$, given $30 \mathrm{~min}$ before the conditioning phase, impaired acquisition of contextual fear conditioning, but not conditioning to a discrete auditory cue (tone), which unlike contextual conditioning is believed to be independent of hippocampal function (Pamplona and Takahashi, 2006). 
This finding is consistent with an impairment of hippocampal functioning, since the hippocampus mediates acquisition of fear conditioning involving contextual cues but not discrete cues (Phillips and LeDoux, 1992). Rimonabant (1 mg/kg) blocked the impairing effects of WIN55212-2, demonstrating the involvement of $\mathrm{CB}_{1}$ receptors (Pamplona and Takahashi, 2006). Sink et al. (2010) showed that administration of $\mathrm{CB}_{1}$ inverse agonists during the acquisition phase improves the retention of the contextual fear, consistent with endogenous cannabinoids having a negative modulatory effect on memory acquisition.

\section{Object recognition and social recognition}

In a typical object recognition task, animals are exposed to an object during one session, and then exposed to the same object plus a novel object in a subsequent test session. The relative amount of time spent exploring the novel object provides an index of memory. Systemic or intra-hippocampal administration of $\Delta^{9}$ THC or WIN55212-2, either acute or repeated, impaired object recognition in rats (Barna et al., 2007; Quinn et al., 2008; Schneider et al., 2008). This impairment is associated with differential expression of proteins in the hippocampus (Quinn et al., 2008). However, in another study acute systemic administration of $\Delta^{9}$ THC before the task failed to affect object recognition in adult rats (Ciccocioppo et al., 2002). Enhanced memory performance was observed in $\mathrm{CB}_{1}$-knockout in this task (Maccarrone et al., 2002).

The roles of hippocampal functioning and spatial learning in the conventional object recognition procedure are still controversial (Ainge et al., 2006; Heuer and Bachevalier, 2011). It is possible to modify the procedure to focus on spatial memory by presenting objects during the exposure phase, then presenting the same objects during the test but with one placed in a different position. Suenaga and Ichitani (2008) found that microinjection of WIN55212-2 (1-2 $\mu \mathrm{g} /$ side in the hippocampus $10 \mathrm{~min}$ before the initial exposure to the objects) did not affect memory in the conventional procedure but impaired in a $\mathrm{CB}_{1}$ dependent fashion the ability to recognize a new spatial configuration of objects.

The social recognition test is similar to the object recognition test but uses conspecifics instead of objects as the stimuli. Using long delays (15-30 $\mathrm{min}$ ) it has been shown that the administration of WIN55212-2 impairs the performance of rats in a $\mathrm{CB}_{1}$ dependent fashion (Schneider and Koch, 2002; Schneider et al., 2008). Rimonabant has been found to enhance recognition memory in this test (Terranova et al., 1996).

\section{Radial maze}

The effects of $\mathrm{CB}_{1}$ compounds on the acquisition and recall of spatial memory in rodents have also been studied using a modified version of the radial maze test. In the conventional version of the test a food pellet is available at the end of each of the eight arms of the maze, and re-entering the same arm more than once indicates a working-memory error. In the modified version, to manipulate the mnemonic demand of the test, the rat is removed from the maze after it enters the seventh arm of the maze, and then it is placed back in the maze after a delay (Lichtman, 2000). With long delays, this test provides a test of long-term memory. Rimonabant $(3 \mathrm{mg} / \mathrm{kg})$, given to rats before the first placement in the maze, reduces the number of errors after a 6-h delay (Lichtman,
2000). Rimonabant had no effect when administered immediately after the first placement (Wise et al., 2007) or before the test placement (Lichtman, 2000), suggesting rimonabant enhances memory acquisition but not consolidation or retrieval. However, in other studies, the facilitating effects of $\mathrm{CB}_{1}$ antagonism have been observed not only for acquisition, but also for consolidation (Wolff and Leander, 2003; Wise et al., 2008).

\section{Passive avoidance}

Data obtained with passive-avoidance procedures suggest a modulatory action of the endocannabinoids system on all phases of memory. In a widely used, hippocampal-dependent version of this test, rodents are allowed to explore a apparatus with two compartments, one lighted and one dark (Isaacson and Wickelgren, 1962). Entrance into the dark compartment is paired with a foot shock during a training session, and increased latency to enter the dark compartment during a subsequent test session is used as an index of conditioning. Systemic injections of $\Delta^{9}$-THC or anandamide or intra-hippocampal injections of WIN55212-2 impair memory acquisition, consolidation, and recall in rats and mice (Castellano et al., 1997; Mishima et al., 2001; Costanzi et al., 2004; Nasehi et al., 2010). However it has been shown that the effects of anandamide on passive-avoidance performance can vary depending on the strain of the animals and on the protocol used (e.g., whether subjects are pre-exposed to the testing apparatus; Castellano et al., 1999; Costanzi et al., 2004).

\section{Caveats}

Taken together, the findings with these various animal models of long-term memory suggest a modulatory role of the endocannabinoid system during the acquisition phase of a place memory (see Table 1). Generally, CB agonists have been found to impair acquisition, and antagonism or deletion of $\mathrm{CB}$ receptors has been found to enhance it. However, there are some caveats to this conclusion. For example, neither the $\mathrm{CB}_{1}$ inverse agonist/antagonist rimonabant at different doses $(1,3 \mathrm{mg} / \mathrm{kg})$ nor the genetic disruption of $\mathrm{CB}_{1}$ receptors facilitated acquisition in the water maze (DaSilva and Takahashi, 2002; Varvel and Lichtman, 2002; Varvel et al., 2007). Several reports have indicated that the effects of $\mathrm{CB}_{1}$ agonists are not limited to acquisition in passive avoidance and delayed radial maze procedures.

In some cases, discrepant results in models of memory may be attributable to cannabinoid effects on other processes. For example, Mikics et al. (2006) reported an enhancement of fear conditioning, rather than an impairment, after administration of WIN55212-2, and tests employing genetic disruption or pharmacological blockade of $\mathrm{CB}_{1}$ receptors indicated that this enhancement of fear conditioning was due to actions of WIN55212-2 at $\mathrm{CB}_{1}$ receptors. Although this finding is inconsistent with the more common finding that $\mathrm{CB}_{1}$ activation impairs memory acquisition, in this case it is possible that WIN55212-2 may have increased anxiety. It is possible that some of the effects of $\mathrm{CB}_{1}$ agonists on water maze behavior are due to thigmotaxis, an anxiety-related tendency to maintain close proximity to the wall of the maze. When Acheson et al. (2011) controlled for thigmotaxis, the impairing effects of WIN55212-2 were no longer detectable.

Another issue to consider is that endocannabinoid receptors localized in different brain structures may modulate distinct 
Table 1 | Summary of studies investigating the effects of cannabinoid receptor agonists, cannabinoid receptor antagonists, FAAH inhibitors, or genetic deletion of cannabinoid receptors on learning and memory in rodents.

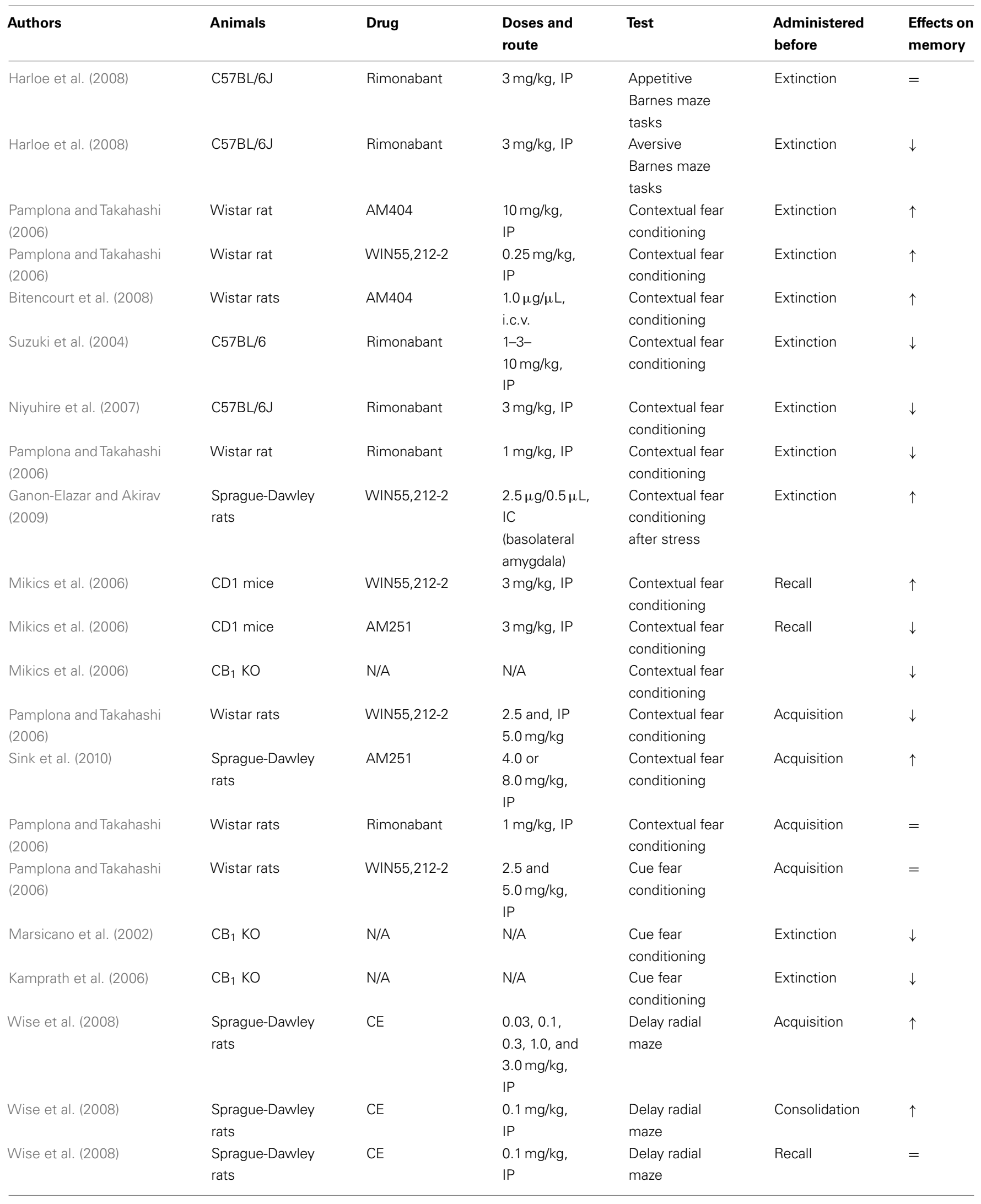


Table 1 | Continued

\begin{tabular}{|c|c|c|c|c|c|c|}
\hline Authors & Animals & Drug & $\begin{array}{l}\text { Doses and } \\
\text { route }\end{array}$ & Test & $\begin{array}{l}\text { Administered } \\
\text { before }\end{array}$ & $\begin{array}{l}\text { Effects on } \\
\text { memory }\end{array}$ \\
\hline Nakamura et al. (1991) & Wistar rats & $\triangle 9-\mathrm{THC}$ & $\begin{array}{l}1.25 \mathrm{mg} / \mathrm{kg}, \\
\mathrm{IP}\end{array}$ & $\begin{array}{l}\text { Delay radial } \\
\text { maze }\end{array}$ & Recall & $=$ \\
\hline Lichtman (2000) & $\begin{array}{l}\text { Sprague-Dawley } \\
\text { rats }\end{array}$ & Rimonabant & $3 \mathrm{mg} / \mathrm{kg}, \mathrm{IP}$ & $\begin{array}{l}\text { Delay radial } \\
\text { maze }\end{array}$ & Acquisition & $\uparrow$ \\
\hline Wise et al. (2007) & $\begin{array}{l}\text { Sprague-Dawley } \\
\text { rats }\end{array}$ & Rimonabant & $1 \mathrm{mg} / \mathrm{kg}, \mathrm{IP}$ & $\begin{array}{l}\text { Delay radial } \\
\text { maze }\end{array}$ & Acquisition & $\uparrow$ \\
\hline Wise et al. (2007) & $\begin{array}{l}\text { Sprague-Dawley } \\
\text { rats }\end{array}$ & Rimonabant & $1 \mathrm{mg} / \mathrm{kg}, \mathrm{IP}$ & $\begin{array}{l}\text { Delay radial } \\
\text { maze }\end{array}$ & Consolidation & $=$ \\
\hline $\begin{array}{l}\text { Wolff and Leander } \\
\text { (2003) }\end{array}$ & $\begin{array}{l}\text { Sprague-Dawley } \\
\text { rats }\end{array}$ & Rimonabant & $1 \mathrm{mg} / \mathrm{kg}, \mathrm{IP}$ & $\begin{array}{l}\text { Delay radial } \\
\text { maze }\end{array}$ & Consolidation & $\uparrow$ \\
\hline Lichtman (2000) & $\begin{array}{l}\text { Sprague-Dawley } \\
\text { rats }\end{array}$ & Rimonabant & $3 \mathrm{mg} / \mathrm{kg}, \mathrm{IP}$ & $\begin{array}{l}\text { Delay radial } \\
\text { maze }\end{array}$ & Recall & $=$ \\
\hline Deadwyler et al. (2007) & Long-Evans rats & WIN55,212-2 & $\begin{array}{l}0,35 \mathrm{mg} / \mathrm{kg} \\
\mathrm{IP}\end{array}$ & DNMTP & $\begin{array}{l}\text { Working- } \\
\text { memory } \\
\text { test }\end{array}$ & $\downarrow$ \\
\hline $\begin{array}{l}\text { Hampson and } \\
\text { Deadwyler (2000) }\end{array}$ & Long-Evans rats & $\triangle 9-\mathrm{THC}$ & $\begin{array}{l}0.5,1.0,1.5 \\
\text { and } \\
2.0 \mathrm{mg} / \mathrm{kg} \\
\text { IP }\end{array}$ & DNMTP & $\begin{array}{l}\text { Working- } \\
\text { memory } \\
\text { test }\end{array}$ & $\downarrow$ \\
\hline Heyser et al. (1993) & $\begin{array}{l}\text { Sprague-Dawley } \\
\text { rats }\end{array}$ & Cannabidiol & $2 \mathrm{mg} / \mathrm{kg}, \mathrm{IP}$ & DNMTP & $\begin{array}{l}\text { Working- } \\
\text { memory } \\
\text { test }\end{array}$ & $\downarrow$ \\
\hline $\begin{array}{l}\text { Mallet and Beninger } \\
\text { (1998) }\end{array}$ & Wistar rats & Anandamide & $2 \mathrm{mg} / \mathrm{kg}, \mathrm{IP}$ & DNMTP & $\begin{array}{l}\text { Working- } \\
\text { memory } \\
\text { test }\end{array}$ & $\downarrow$ \\
\hline Deadwyler et al. (2007) & Long-Evans rats & Rimonabant & $2 \mathrm{mg} / \mathrm{kg}, \mathrm{IP}$ & DNMTP & $\begin{array}{l}\text { Working- } \\
\text { memory } \\
\text { test }\end{array}$ & $\uparrow$ \\
\hline $\begin{array}{l}\text { Mallet and Beninger } \\
\text { (1998) }\end{array}$ & Wistar rats & Rimonabant & $2 \mathrm{mg} / \mathrm{kg}, \mathrm{IP}$ & DNMTP & $\begin{array}{l}\text { Working- } \\
\text { memory } \\
\text { test }\end{array}$ & $=$ \\
\hline Chhatwal et al. (2005) & $\begin{array}{l}\text { Sprague-Dawley } \\
\text { rats }\end{array}$ & $\begin{array}{l}\text { WIN } \\
55,212-2\end{array}$ & $5 \mathrm{mg} / \mathrm{kg}, \mathrm{IP}$ & $\begin{array}{l}\text { Fear } \\
\text { potentiated } \\
\text { startle } \\
\text { response }\end{array}$ & Extinction & $=$ \\
\hline Chhatwal et al. (2005) & $\begin{array}{l}\text { Sprague-Dawley } \\
\text { rats }\end{array}$ & AM404 & $\begin{array}{l}10 \mathrm{mg} / \mathrm{kg} \\
\mathrm{IP}\end{array}$ & $\begin{array}{l}\text { Fear } \\
\text { potentiated } \\
\text { startle } \\
\text { response }\end{array}$ & Extinction & $\uparrow$ \\
\hline
\end{tabular}


Table 1 | Continued

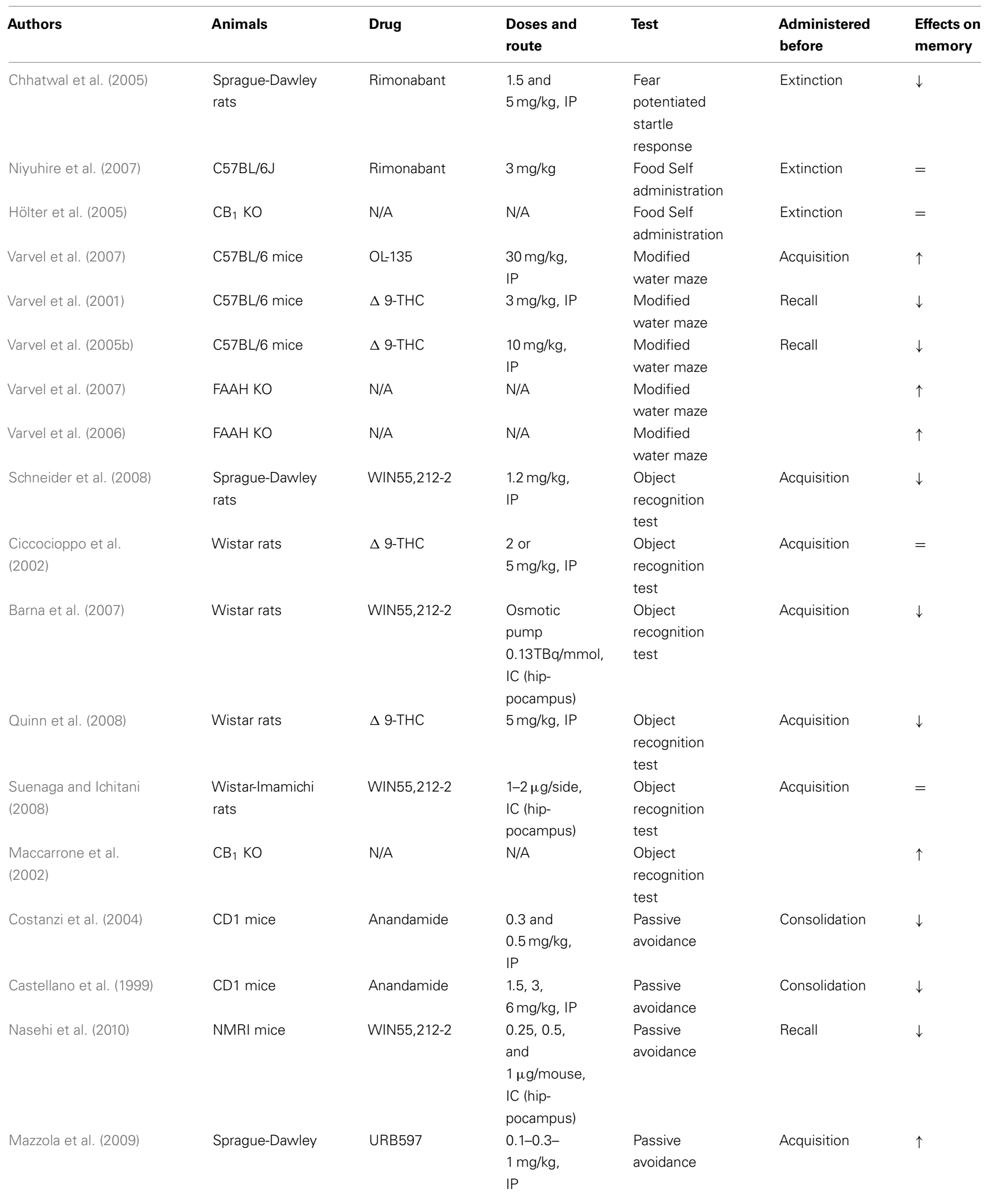


Table 1 | Continued

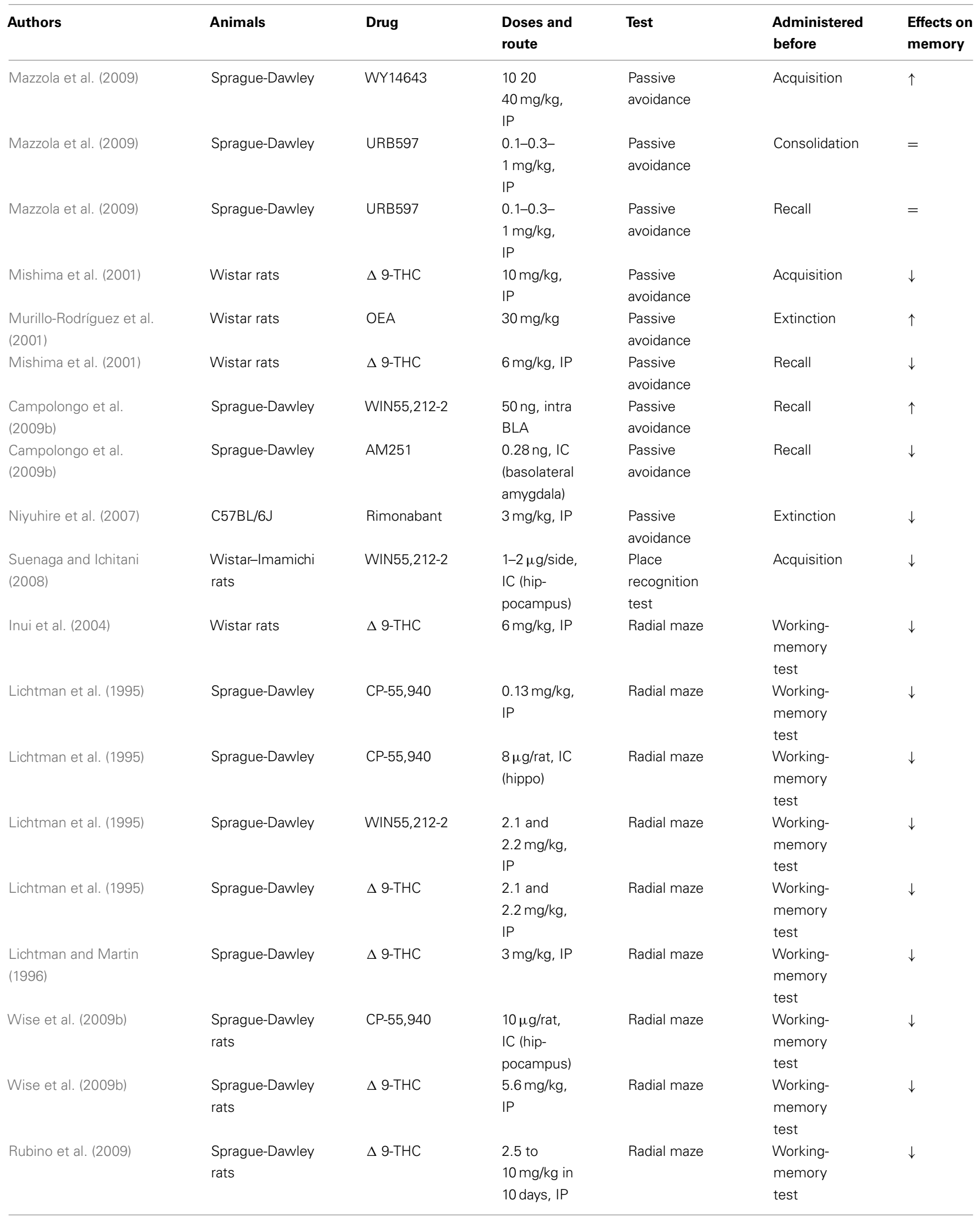


Table 1 | Continued

\begin{tabular}{|c|c|c|c|c|c|c|}
\hline Authors & Animals & Drug & $\begin{array}{l}\text { Doses and } \\
\text { route }\end{array}$ & Test & $\begin{array}{l}\text { Administered } \\
\text { before }\end{array}$ & $\begin{array}{l}\text { Effects on } \\
\text { memory }\end{array}$ \\
\hline Egashira et al. (2002) & Wistar rats & $\triangle 9-\mathrm{THC}$ & $\begin{array}{l}20 \mu \mathrm{g} / \mathrm{side} \text {, } \\
\text { IC (hip- } \\
\text { pocampus) }\end{array}$ & Radial maze & $\begin{array}{l}\text { Working- } \\
\text { memory } \\
\text { test }\end{array}$ & $\downarrow$ \\
\hline Egashira et al. (2008) & Wistar rats & $\triangle 9-T H C$ & $6 \mathrm{mg} / \mathrm{kg}, \mathrm{IP}$ & Radial maze & $\begin{array}{l}\text { Working- } \\
\text { memory } \\
\text { test }\end{array}$ & $\downarrow$ \\
\hline $\begin{array}{l}\text { Molina-Holgado et al. } \\
\text { (1993) }\end{array}$ & Wistar rats & $\triangle 9-T H C$ & $\begin{array}{l}5 \mathrm{mg} / \mathrm{kg} \\
\mathrm{PO}\end{array}$ & Radial maze & $\begin{array}{l}\text { Working- } \\
\text { memory } \\
\text { test }\end{array}$ & $\downarrow$ \\
\hline Nakamura et al. (1991) & Wistar rats & $\triangle 9-\mathrm{THC}$ & $\begin{array}{l}1.25 \mathrm{mg} / \mathrm{kg} \\
\mathrm{IP}\end{array}$ & Radial maze & $\begin{array}{l}\text { Working- } \\
\text { memory } \\
\text { test }\end{array}$ & $\downarrow$ \\
\hline Mishima et al. (2001) & & $\Delta 9-\mathrm{THC}$ & $\begin{array}{l}4-6 \mathrm{mg} / \mathrm{kg} \\
\text { IP }\end{array}$ & Radial maze & $\begin{array}{l}\text { Working- } \\
\text { memory } \\
\text { test }\end{array}$ & $\downarrow$ \\
\hline Varvel et al. (2005b) & C57BL/6 mice & $\triangle 9-\mathrm{THC}$ & $10 \mathrm{mg} / \mathrm{kg}$ & T-maze & $\begin{array}{l}\text { Working- } \\
\text { memory } \\
\text { test }\end{array}$ & $\downarrow$ \\
\hline Nava et al. (2001) & Sprague-Dawley & $\triangle 9-\mathrm{THC}$ & $\begin{array}{l}2.5 \text { and } \\
5 \mathrm{mg} / \mathrm{kg}, \mathrm{IP}\end{array}$ & T-maze & $\begin{array}{l}\text { Working- } \\
\text { memory } \\
\text { test }\end{array}$ & $\downarrow$ \\
\hline Jentsch et al. (1998) & Sprague-Dawley & $\Delta$ 9-THC & $5 \mathrm{mg} / \mathrm{kg}, \mathrm{IP}$ & T-maze & $\begin{array}{l}\text { Working- } \\
\text { memory } \\
\text { test }\end{array}$ & $\downarrow$ \\
\hline Varvel et al. (2007) & C57BL/6J & OL-135 & $\begin{array}{l}30 \mathrm{mg} / \mathrm{kg} \\
\mathrm{IP}\end{array}$ & Water maze & Extinction & $\uparrow$ \\
\hline Robinson et al. (2010) & $\begin{array}{l}\text { Lister Hooded } \\
\text { rats }\end{array}$ & WIN55,212-2 & $\begin{array}{l}1 \text { and } \\
3 \mathrm{mg} / \mathrm{kg}, \mathrm{IP}\end{array}$ & Water maze & Acquisition & $\downarrow$ \\
\hline Moore et al. (2010) & $\begin{array}{l}\text { Sprague-Dawley } \\
\text { CD rats }\end{array}$ & $\triangle 9-\mathrm{THC}$ & $\begin{array}{l}10 \mathrm{mg} / \mathrm{kg} \\
\mathrm{IP}\end{array}$ & Water maze & Acquisition & $\downarrow$ \\
\hline Diana et al. (2003) & $\begin{array}{l}\text { Sprague-Dawley } \\
\text { rats }\end{array}$ & Nabilone & $\begin{array}{l}0.1,0.5 \text {, } \\
\text { and } \\
1.0 \mathrm{mg} / \mathrm{kg} \text {, } \\
\mathrm{IP}\end{array}$ & Water maze & Acquisition & $=$ \\
\hline Acheson et al. (2011) & $\begin{array}{l}\text { Sprague-Dawley } \\
\text { rats }\end{array}$ & WIN55,212-2 & $1 \mathrm{mg} / \mathrm{kg}, \mathrm{IP}$ & Water maze & Acquisition & $=$ \\
\hline Diana et al. (2003) & $\begin{array}{l}\text { Sprague-Dawley } \\
\text { rats }\end{array}$ & $\triangle 8-\mathrm{THC}$ & $5 \mathrm{mg} / \mathrm{kg}, \mathrm{IP}$ & Water maze & Acquisition & $\downarrow$ \\
\hline $\begin{array}{l}\text { DaSilva and Takahashi } \\
\text { (2002) }\end{array}$ & Swiss albino & $\triangle 9-\mathrm{THC}$ & $8 \mathrm{mg} / \mathrm{kg}, \mathrm{IP}$ & Water maze & Acquisition & $\downarrow$ \\
\hline
\end{tabular}


Table 1 | Continued

\begin{tabular}{|c|c|c|c|c|c|c|}
\hline Authors & Animals & Drug & $\begin{array}{l}\text { Doses and } \\
\text { route }\end{array}$ & Test & $\begin{array}{l}\text { Administered } \\
\text { before }\end{array}$ & $\begin{array}{l}\text { Effects on } \\
\text { memory }\end{array}$ \\
\hline Ferrari et al. (1999) & $\begin{array}{l}\text { Wistar } \\
\text { Hannover rat }\end{array}$ & HU-210 & $\begin{array}{l}50 \text { and } \\
100 \mu \mathrm{g} / \mathrm{kg} \text {, } \\
\text { IP }\end{array}$ & Water maze & Acquisition & $\downarrow$ \\
\hline Mishima et al. (2001) & Wistar rats & $\Delta$ 9-THC & $\begin{array}{l}6 \text { and } \\
10 \mathrm{mg} / \mathrm{kg} \\
\text { IP }\end{array}$ & Water maze & Recall & $=$ \\
\hline Varvel et al. (2007) & C57BL/6 mice & Rimonabant & $3 \mathrm{mg} / \mathrm{kg}, \mathrm{IP}$ & Water maze & Acquisition & $=$ \\
\hline Varvel et al. (2007) & C57BL/6 mice & Rimonabant & $3 \mathrm{mg} / \mathrm{kg}, \mathrm{IP}$ & Water maze & Acquisition & $=$ \\
\hline Varvel et al. (2005a) & C57BL/6J & Rimonabant & $3 \mathrm{mg} / \mathrm{kg}, \mathrm{IP}$ & Water maze & Extinction & $\downarrow$ \\
\hline $\begin{array}{l}\text { DaSilva and Takahashi } \\
\text { (2002) }\end{array}$ & $\begin{array}{l}\text { Swiss albino } \\
\text { mice }\end{array}$ & Rimonabant & $1 \mathrm{mg} / \mathrm{kg}, \mathrm{IP}$ & Water maze & Acquisition & $=$ \\
\hline Varvel et al. (2005a) & $\mathrm{CB}_{1} \mathrm{KO}$ & N/A & N/A & Water maze & (Extinction) & $\downarrow$ \\
\hline Varvel et al. (2007) & FAAH KO & N/A & N/A & Water maze & (Extinction) & $\uparrow$ \\
\hline Varvel et al. (2006) & FAAH KO & N/A & N/A & Water maze & $\begin{array}{l}\text { Working- } \\
\text { memory } \\
\text { test }\end{array}$ & $\uparrow$ \\
\hline Varvel et al. (2007) & FAAH KO & N/A & N/A & Water maze & & $\uparrow$ \\
\hline Varvel et al. (2006) & FAAH KO & N/A & N/A & $\begin{array}{l}\text { Water maze } \\
\text { reversal } \\
\text { learning }\end{array}$ & & $\uparrow$ \\
\hline $\begin{array}{l}\text { Varvel and Lichtman } \\
\text { (2002) }\end{array}$ & $\mathrm{CB}_{1} \mathrm{KO}$ & N/A & N/A & Water maze & & $=$ \\
\hline
\end{tabular}

DNMTP, delayed non-matching to position; KO, knockout; WT, wild type. For effects on memory, $\downarrow$ indicates impairment; $\uparrow$ indicates enhancement; $=$ indicates no effect.

memory process. This may explain cases where microinfusion of cannabinoid compounds into specific areas produces effects opposite to those usually seen with systemic administration. For example, Campolongo et al. (2009b) found that micro-injections of WIN55212-2 into the basolateral amygdala enhanced memory retention and the $\mathrm{CB}_{1}$ antagonist AM251 caused impairments in a passive-avoidance test.

\section{WORKING MEMORY}

Working memory involves the temporary storage and manipulation of information. The memory impairments induced by cannabis and $\Delta^{9}$-THC in humans are most robust in tests of shortterm episodic and working memory (Ranganathan and D'Souza, 2006). In animal models, the effects of cannabinoids on working memory have received much attention (see Table 1), and the data appear more congruent than in the models of long-term reference memory discussed above. Some of the procedures used to study working memory are adapted from procedures used to study acquisition of long-term memory.

\section{Water maze}

The basic water maze procedure can be modified to test working memory by changing the location of the platform each day and testing with only a brief delay between acquisition and a test trial. Varvel et al. (2001) have demonstrated that $\Delta^{9}$-THC administered before the testing session impairs memory in a $\mathrm{CB}_{1}$ dependent manner without affecting locomotion.

\section{Radial maze}

The findings obtained with the working-memory version of the water maze procedure agree with those obtained with the conventional version of the radial maze, which focuses on working memory. In rodents, systemic administration of $\Delta^{9}-\mathrm{THC}$ or $\mathrm{CB}_{1}$ agonists like WIN55212 or CP-55,940 increase the number of errors (Molina-Holgado et al., 1993; Lichtman et al., 1995; Lichtman and Martin, 1996; Mishima et al., 2001). Interestingly, Nakamura et al. (1991) found that $\Delta^{9}$-THC (given $30 \mathrm{~min}$ before the task) impaired performance in the test when a short delay of $5 \mathrm{~s}$ was introduced between entering the fourth and fifth arms, but not when the delay was longer $(1 \mathrm{~h})$; this suggests a more prominent effect of $\Delta^{9}$-THC on working memory than on long-term reference memory. However, under a similar task Silva de Melo et al. (2005) obtained opposite results, with systemic or intra medial prefrontal cortex administration of THC selectively impairing memory in the long-delay condition.

A series of experiments exploring the brain structure involved in cannabinoid-induced impairments of working memory in the radial maze have shown that both the hippocampus and prefrontal cortex are involved (Egashira et al., 2002; Silva de Melo et al., 2005; Suenaga et al., 2008; Rubino et al., 2009; Wise et al., 2009b; Rodrigues et al., 2011) and that $\mathrm{CB}_{1}$ and $\mathrm{D}_{1-2}$ receptors play critical roles (Wise et al., 2009b; Rodrigues et al., 2011).

\section{T-maze}

T-maze procedures also provide a test of spatial working memory. There are two goal arms, and rodents obtain food by entering 
the goal arm that was not entered on the previous trial. Systemic administration of $\Delta^{9}$-THC (Jentsch et al., 1998; Nava et al., 2001; Varvel et al., 2005b) or intra-hippocampal administration of WIN55212 (Suenaga et al., 2008) impairs the performance of and rats, and $\mathrm{CB}_{1}$ antagonists reverse these effects. Several lines of evidence indicate the involvement of acetylcholine systems in the effects of $\Delta^{9}$-THC on working memory in task such as the T-maze and radial maze. Extracellular levels of hippocampal acetylcholine have been shown to decrease after $\Delta^{9}$-THC administration (Mishima et al., 2002), and drugs that reestablish levels of this neurotransmitter can reverse the impairing effects of $\Delta^{9}$-THC (Nava et al., 2000, 2001; Mishima et al., 2002; Inui et al., 2004; Wise et al., 2007; Egashira et al., 2008).

\section{Delayed spatial matching}

Extensive studies of working memory have been performed by Hampton, Deadwyler, and associates, using the delayed nonmatching to position task in rats. In this task, one of two retractable levers is extended as a sample. After the rat presses the sample lever, the lever is retracted. After a delay period, both levers are extended and the rat receives food or water if it presses the nonmatching lever (i.e., the one that was not presented as a sample; Deadwyler et al., 1996; Mallet and Beninger, 1998). Many such trials can be conducted during a daily session, with the length of the delay varied across trials. Administration of $\Delta^{9}$-THC, anandamide, or WIN55212-2 before the session impairs performance (Heyser et al., 1993; Mallet and Beninger, 1998; Hampson and Deadwyler, 2000; Deadwyler et al., 2007; Goonawardena et al., 2010; Panlilio et al., 2011). This effect is associated with a druginduced decrease in the firing rate of hippocampal pyramidal neurons during the initiation of the trial; preadministration of rimonabant (IP $1.5 \mathrm{mg} / \mathrm{kg}$ ) reestablishes a normal level of hippocampal neuronal activity and blocks the memory-impairing effects of $\Delta^{9}$-THC and WIN55,212-2 (Hampson and Deadwyler, 2000; Goonawardena et al., 2010). Under some conditions, the administration of a higher concentration (IP, $2 \mathrm{mg} / \mathrm{mL}$ ) of rimonabant alone can enhance performance in this working-memory task (Deadwyler and Hampson, 2008). However, this result has not been reported consistently by the Deadwyler lab and was not obtained with the same dose of rimonabant in a study by Mallet and Beninger (1998). Possibly, the enhancing effect is sometimes prevented by ceiling effects and requires modifications of the procedure (e.g., longer delay periods) to be observed.

\section{ENHANCED ANANDAMIDE SIGNALING AND PPAR- $\alpha$ ACTIVATION}

Compounds that inhibit the activity of the fatty acid amide hydrolase enzyme (FAAH) prevent the degradation of endocannabinoid anandamide and thereby magnify and prolong anandamide's actions (Kathuria et al., 2003). FAAH inhibition also increases levels of several other fatty acids - oleoylethanolamide (OEA) and palmitoylethanolamide (PEA) - that constitute endocannabinoidlike systems in the brain (Fegley et al., 2005). OEA and PEA do not bind to cannabinoid receptors, but are ligands for alpha-type peroxisome proliferator-activated nuclear receptors (PPAR- $\alpha$ ). PPAR$\alpha$ is well known to be involved in a number of physiological processes, but is just beginning to received attention for having cognitive and other behavioral effects (Mazzola et al., 2009; Melis et al., 2010; Mascia et al., 2011).
Surprisingly, given the preponderance of findings that cannabinoid agonists impair memory and the fact that FAAH inhibitors increase levels of the endogenous cannabinoid agonist anandamide, FAAH inhibitors have been found to enhance learning in several procedures. The FAAH inhibitor OL-135 $(30 \mathrm{mg} / \mathrm{kg})$ enhanced the acquisition rate in a working-memory version of the water maze test or in the conventional fixed-platform test in (Varvel et al., 2007); however, the same dose of OL-135 did not have such effects in an earlier study (Varvel et al., 2006). Another FAAH inhibitor, URB597 (0.1-1 mg/kg), enhanced the acquisition of passive-avoidance learning, but was not found to affect consolidation or retrieval (Mazzola et al., 2009). In genetically modified FAAH-compromised mice, acquisition was enhanced in the working-memory water maze test, but not in the conventional, fixed-platform of test (Varvel et al., 2007; Wise et al., 2009a).

Although both Varvel et al. (2007) and Mazzola et al. (2009) found that rimonabant $(1 \mathrm{mg} / \mathrm{kg}$ in rats; $3 \mathrm{mg} / \mathrm{kg}$ in mice) was able to block the facilitating effects of FAAH inhibition on memory acquisition, suggesting mediation by $\mathrm{CB}_{1}$ receptors, there is evidence that non-cannabinoid effects of FAAH inhibition also can enhance learning and memory. Mazzola et al. (2009) found that the enhancing effects of FAAH inhibition on passive-avoidance learning could be blocked not only by rimonabant but by the PPAR- $\alpha$ antagonist MK886. This suggests that FAAH inhibition might enhance memory by increasing the levels of the endogenous PPAR- $\alpha$ ligands OEA and PEA. Consistent with this hypothesis, the PPAR- $\alpha$ agonist WY14643 produced effects similar to those of the FAAH inhibitor URB597 on acquisition of passiveavoidance test, and this effect of WY14643 was also blocked by the PPAR- $\alpha$ antagonist MK886. In both a passive avoidance and a fixed-platform water maze procedure in rats, administration of exogenous OEA enhanced memory (Campolongo et al., 2009a). However, it should be noted that in the study where the FAAH inhibitor OL-135 did not enhance water maze learning (Varvel et al., 2006), OEA (50 mg/kg) and PEA (50 mg/kg) also failed to affect working memory in the water maze. In addition, while Mazzola et al. (2009) found that FAAH inhibition or administration of the PPAR- $\alpha$ agonist WY14643 specifically affected acquisition of passive avoidance, Campolongo et al. (2009a) found that OEA had effects when given immediately post-training, indicating an effect on consolidation.

The finding that FAAH inhibition has memory effects opposite to those of cannabinoid agonists might be at least partially explained by differences in the brain areas affected by these two kinds of treatment. As mentioned above, systemic injection of a drug such as $\Delta^{9}$-THC affects $\mathrm{CB}_{1}$ receptors throughout the brain. Systemic injection of a FAAH inhibitor selectively increasing anandamide levels in areas where it is being released. It is likely that different brain areas subserve different mnemonic processes; for example, endocannabinoid signaling in the hippocampus might be more involved in acquisition, while endocannabinoid signaling in the amygdala might be more involved in consolidation and forgetting (Riedel and Davies, 2005).

\section{EXTINCTION AND FORGETTING}

While the fact that exogenous cannabinoids impair memory has been studied in humans and animals for decades, it has only 
recently been recognized that endocannabinoid systems might be involved in extinction learning. Extinction learning refers to the cessation of a learned response when the conditions that induced the learning no longer hold. For example, after the initial exposure to shock in contextual fear conditioning, the conditioned freezing response will gradually decrease if the subject is repeatedly exposed to the context but no longer shocked. This loss of the learned response might be described as forgetting, or as the establishment of new learning appropriate to the current situation.

Using fear conditioning with a discrete cue, Marsicano et al. (2002) were the first to report compromised extinction learning in $\mathrm{CB}_{1}$-knockout mice and in wild type mice given rimonabant $(3 \mathrm{mg} / \mathrm{kg})$. Interestingly, the behavioral patterns observed in $\mathrm{CB}_{1}$-knockout and rimonabant-treated mice were associated with decreased long-term depression of neurons in the amygdala, a structure known to play a critical role in extinction learning (Quirk and Mueller, 2008). Moreover, presentation of the shockassociated tone during extinction was followed by increased release of anandamide in the basolateral amygdala of wild type mice, suggesting the involvement of endocannabinoid neurotransmission in extinction learning (Marsicano et al., 2002). It has been proposed that endocannabinoids modulate fear-related extinction learning by regulating the activity of kinases and phosphatases in regions involved in fear and memory processing (Cannich et al., 2004).

The impairing effects of genetic and pharmacological blockade of $\mathrm{CB}_{1}$ receptors on extinction learning, but not on the acquisition of long-term and short-term fear-related memory, has been replicated in many laboratories with rats and mice (Suzuki et al., 2004; Chhatwal et al., 2005; Kamprath et al., 2006; Niyuhire et al., 2007; Pamplona et al., 2008). Also consistent with the hypothesis that $\mathrm{CB}_{1}$ dependent mechanisms modulate extinction learning, activation of $\mathrm{CB}_{1}$ receptors has been shown to facilitate fear conditioning, producing effects opposite to those of $\mathrm{CB}_{1}$ antagonists. Administration of the anandamide uptake inhibitor AM404 (IP: $10 \mathrm{mg} / \mathrm{kg} ; 1.0 \mu \mathrm{g} / \mu \mathrm{L}$, i.c.v.) during extinction training facilitated the extinction of startle or freezing elicited by a shock-associated context (Chhatwal et al., 2005; Bitencourt et al., 2008; Pamplona et al., 2008); this effect was $\mathrm{CB}_{1}$ dependent, since it is blocked by a dose of rimonabant that was ineffective by itself (Bitencourt et al., 2008). Low doses $(0.25 \mathrm{mg} / \mathrm{kg}, \mathrm{IP})$ but not a high dose $(5 \mathrm{mg} / \mathrm{kg})$ of the $\mathrm{CB}_{1}$ agonist WIN55,212-2 impaired contextual fear conditioning under the same conditions where rimonabant enhanced it (Chhatwal et al., 2005; Pamplona and Takahashi, 2006). Moreover Ganon-Elazar and Akirav (2009) have shown that micro-injection of a low dose of WIN55,2122 in the basolateral amygdala has no effect by itself but can reverse the disrupting effect of a stressor on extinction of passive avoidance.

The effects of cannabinoid compounds on extinction learning have also been confirmed with another aversively motivated test, the water maze. In this test, Varvel et al. (2005b, 2007) found that rimonabant $(3 \mathrm{mg} / \mathrm{kg})$ treatment or genetic $\mathrm{CB}_{1}$ disruption impaired extinction learning, but THC did not affect extinction (Varvel et al., 2007). Surprisingly, pharmacological and genetic manipulations of $\mathrm{CB}_{1}$ have not been found to affect extinction learning in tasks based on appetitive conditioning (Hölter et al., 2005; Niyuhire et al., 2007; Harloe et al., 2008).
It has been suggested that the effects of $\mathrm{CB}_{1}$ antagonism in extinction procedures may depend on perseverance. For example, rimonabant-treated or $\mathrm{CB}_{1}$-knockout mice show deficits in learning when the platform is moved to a new location in the water maze test (Varvel and Lichtman, 2002; Pamplona et al., 2006). However this view is not supported by another study in which certain doses of $\mathrm{CB}_{1}$ agonists and antagonists facilitated or impaired, respectively, flexibility between different strategies (Hill et al., 2006). In this experiment, separate groups of rats were trained to use either a visual cue or a spatial (left vs. right) strategy to locate food in one arm of a plus-maze. Flexibility was then measured as the number of perseverative errors when the opposite strategy was required. Administration of the $\mathrm{CB}_{1}$ antagonist AM251 (2 mg/kg) $20 \mathrm{~min}$ before testing reduced perseverative errors, whereas the $\mathrm{CB}_{1}$ agonist $\mathrm{HU}-210(20 \mu \mathrm{g} / \mathrm{kg}, \mathrm{IP})$ increased them.

The effects of FAAH inhibition on extinction learning have also been studied. FAAH null mice and mice treated with the FAAH inhibitor OL-135 show enhanced extinction learning in the water maze test (Varvel et al., 2007). Therefore FAAH inhibitors have unique effects among the endocannabinoid-related compounds, facilitating both acquisition and extinction processes. This characteristic may be due, as previously mentioned, to the ability of FAAH inhibitors to increase not only brain levels of anandamide but also of PEA and OEA. Indeed it has been shown that OEA administration $(30 \mathrm{mg} / \mathrm{kg})$ can facilitate extinction of passive avoidance in rats (Murillo-Rodríguez et al., 2001).

\section{CONCLUSION - ENDOCANNABINOID SIGNALING AND COGNITION}

Most of the evidence indicates that activating the endocannabinoid system interferes with situation-dependent working memory and the acquisition of long-term memory (see Table 1). Inhibiting the endocannabinoid system, on the other hand, can enhance learning and memory. Surprisingly, increasing endogenous levels of anandamide and facilitating endocannabinoid signaling with a FAAH inhibitor can enhance learning; but, this probably occurs through the endocannabinoid-related PPAR- $\alpha$ system and the fatty acids OEA and PEA. There is accumulating evidence that the endocannabinoid system plays a special role in extinction learning related to aversive conditioning. This role, along with its role in emotion, suggests cannabinoid-related medications might be developed for treating phobias.

\section{EFFECTS OF ENDOCANNABINOID SYSTEM MODULATION ON EMOTIONAL BEHAVIOR}

The effects of cannabinoid agonists and antagonists on emotional behavior have recently been reviewed elsewhere (Bambico et al., 2009; Moreira and Wotjak, 2010) and will only be discussed briefly here. Instead, we will focus on studies that involve genetic disruption of $\mathrm{CB}_{1}$ receptors or genetic or pharmacological manipulation of the anandamide-degrading enzyme FAAH. These methods generally provide more direct information about endocannabinoid function because they exclude or enhance cannabinoid signaling, rather than directly stimulating cannabinoid receptors.

The animal models of anxiety that have been used with these endocannabinoid manipulations generally measure changes in rodents' tendency to avoid certain inherently aversive situations; 
increased avoidance implies increased anxiety (an anxiogenic effect), and decreased avoidance indicates decreased anxiety (an anxiolytic effect). The avoided situations include brightly lit areas (light/dark test), open areas (open field test), open elevated areas (elevated plus-maze and O-maze tests), social interaction with unfamiliar conspecifics (social interaction test), and painassociated stimuli (Vogel conflict test, shock prod burying test). In most of these tests, locomotor activity can also be monitored to assess the possibility that a drug or dose is causing non-specific sedation or motor depression, rather than affecting emotional behavior. Animal tests of depression generally model specific depression-like symptoms. For example, some tests measure changes in rodents' tendency to eventually becoming immobile when it is not possible to escape from water (forced swim test) or being suspended by the tail (tail suspension test). A decrease in the duration of immobility is considered an antidepressantlike effect and an increase in duration a depressant-like effect. Increased immobility is believed to be a sign of "behavioral despair" that putatively models the depression symptoms "loss of energy" and/or "feelings of hopelessness." A depression-like state can be induced in laboratory rodents by exposing them to mild but recurrent and unpredictable stressors (chronic mild stress model). In this model, a decrease in consumption of sucrose is believed to model anhedonia (loss of pleasure) another important symptom of depression in humans.

\section{EFFECTS OF CB ${ }_{1}$ RECEPTOR AGONISTS AND ANTAGONISTS ON EMOTIONAL BEHAVIOR}

Cannabinoid receptor agonists decrease depression-like behaviors in a variety of species and models (Bambico et al., 2009). For example, in the forced swim test the $\mathrm{CB}_{1}$ agonists anandamide, $\Delta$ 9-THC, CP-55,940, HU-210, and WIN55,212-2 decrease immobility in the forced swim paradigm in BALB/C and CD1 mice and in Long-Evans, Sprague-Dawley, and Wistar rats, effects that are blocked by the $\mathrm{CB}_{1}$ antagonists rimonabant and AM251. Although these findings suggest that cannabinoid receptor agonists hold promise as targets for the treatment of depression, these drugs have significant side effects (e.g., psychosis and panic) that preclude their clinical use (Moreira et al., 2009). Similarly, $\mathrm{CB}_{1}$ antagonists also been found to have both therapeutic potential and unacceptable side effects; the antagonist rimonabant, which showed promise as a treatment for obesity, was recalled from the market because of emotional, depression-like side effects.

The effects of cannabinoid agonists are somewhat more complex in animal models of anxiety than in animal models of depression. High and low doses of cannabinoid agonists often have opposite effects (Moreira and Wotjak, 2010), with low doses inducing anxiolytic effects, while high doses induce anxiogenic effects. Both effects can be inhibited by $\mathrm{CB}_{1}$ antagonists, although paradoxical agonist/antagonist interactions have also been reported (Haller et al., 2007).

\section{Caveats}

Discrepant findings with $\mathrm{CB}_{1}$ receptor ligands are usually attributed to differences in dosage and treatment duration, experimental conditions, and species (Bambico et al., 2009; Moreira and Wotjak, 2010). However, these factors have rarely been studied systematically, and the reasons for discrepant findings are actually poorly understood. One possible explanation lies in the fact that $\mathrm{CB}_{1}$ receptors are expressed on both glutamatergic and GABAergic synapses and these neurotransmitter systems often have opposite effects on emotions, especially on anxiety. We have shown that the relative cannabinoid sensitivity of GABA and glutamate neurotransmission differs between CD1 and Wistar rats and that these differences are likely responsible for the differential effects of cannabinoids on anxiety in these two species (Haller et al., 2007). Similar differences in cannabinoid function might be present in different strains of the same species, or even individual subjects. Thus, discrepant findings could be due to differences in the expression, distribution, and functional characteristics of $\mathrm{CB}_{1}$ receptors.

\section{GENETIC DELETION OF CB $_{1}$ RECEPTORS}

The impact of genetic deletion of $\mathrm{CB}_{1}$ in animal models of anxiety and depression was demonstrated in three studies published in 2002 (see Table 2). Maccarrone et al. (2002) showed that $\mathrm{CB}_{1}$ knockout mice were more anxious than wild type in the open field and light/dark tests; however, this effect was present in young mice but not in 4-month-old mice. Martin et al. (2002) reported that deletion of the $\mathrm{CB}_{1}$ gene induced signs of anxiety in the light/dark test and depression-like symptoms in the sucrose consumption test after chronic mild stress. Finally, Haller et al. (2002) showed that $\mathrm{CB}_{1}$-knockout mice robustly express anxiety in the elevated plus-maze, but this kind of effect was not induced by the $\mathrm{CB}_{1}$ antagonist rimonabant in wildtype mice. A later study by the same group found that, unlike rimonabant but like $\mathrm{CB}_{1}$ deletion, the $\mathrm{CB}_{1}$ antagonist AM251 did increase anxiety (Haller et al., 2004b). Subsequent studies have also replicated the depressionlike phenotype of $\mathrm{CB}_{1}$-knockout mice in the forced swim test (Fride et al., 2005), but others have not (Steiner et al., 2008a,b). Conditional mutants lacking $\mathrm{CB}_{1}$ receptors at their cortical glutamatergic neurons showed decreased immobility in the forced swim test, suggesting an antidepressant effect of this more targeted genetic manipulation (Steiner et al., 2008b).

Like the depressant effects, the anxiogenic effects of $\mathrm{CB}_{1}$ deletion have been replicated in a number of studies using a variety of procedures (see Table 2). These include the elevated plus-maze, social interaction, and light/dark tests (Urigüen et al., 2004; Mikics et al., 2009; Hill et al., 2011). In other cases, however, the effect was weak. For example, risk assessment was decreased in the elevated plus-maze, but open arm exploration (the main measure of anxiety in this test) was not affected (Jacob et al., 2009). Also, mutant mice lacking the $\mathrm{CB}_{1}$ receptor at their glutamatergic synapses showed no changes in anxiety (Jacob et al., 2009). The effects of gene disruption were also weak in the mouse defense test battery, a less commonly used but behaviorally valid model of anxiety that measures responses to an unconditioned predator-related stimulus (Griebel et al., 2005). In one study, the anxiolytic effects of ethanol were not diminished in $\mathrm{CB}_{1}$-knockout in the elevated plusmaze (Houchi et al., 2005). In another experiment that used the shock prod burying test, $\mathrm{CB}_{1}$ deletion itself had anxiolytic effects (Degroot and Nomikos, 2004).

Some of the inconsistency in the effects of $\mathrm{CB}_{1}$ on anxietyand depression-like behavior might be due to changes in 
Table 2 | Summary of studies investigating anxiety-like and depression-like behavior in knockout with cannabinoid $\mathrm{CB}_{1}$ with deleted.

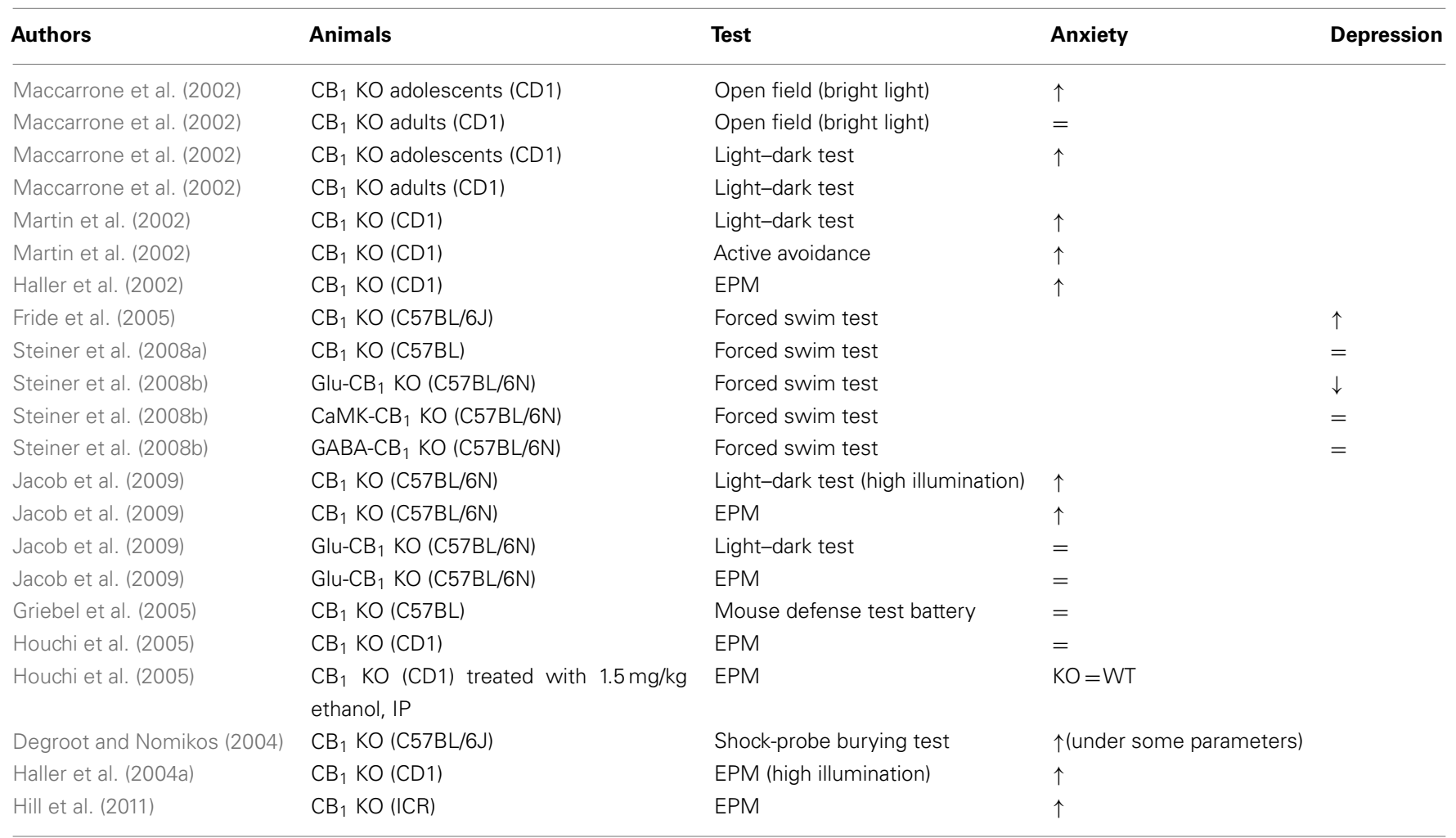

EPM, elevated plus-maze; KO, knockout; WT, wild type. For effects in models of anxiety and depression, $\downarrow$ indicates impairment; $\uparrow$ indicates enhancement; $=$ indicates no effect.

responsiveness to environmental stimuli. In a recent study, Jacob et al. (2009) showed that behavioral differences between wild type and $\mathrm{CB}_{1}$-knockout mice were strongly influenced by the level of illumination under which the test was performed; in models of anxiety, such as the open field and the elevated plus-maze the behavior of $\mathrm{CB}_{1}$-knockout differed markedly depending on light intensity. The impact of light intensity was also studied by Haller et al. (2004a), who reported that the anxiogenic effects of $\mathrm{CB}_{1}$ gene disruption are evident when mice are tested in light, but not when they are tested in darkness. The same study suggested that the impact of $\mathrm{CB}_{1}$ gene deletion on social behaviors depends on the level of familiarity with the testing environment; opposite effects were obtained in the home-cage and in an unfamiliar cage. Even the study where $\mathrm{CB}_{1}$ deletion had an anxiolytic effect (Degroot and Nomikos, 2004) can be perceived as a particular case of the interaction between environmental stimuli and $\mathrm{CB}_{1}$-knockout behavior, as the shock prod burying test examines the immediate behavioral response to electric shocks.

Taken together, these findings suggest that deletion of endogenous $\mathrm{CB}_{1}$ signaling generally produces an anxious phenotype, but this effect is strongly dependent on environmental conditions. Intriguingly, Hill et al. (2011) recently demonstrated that the behavioral and neural changes associated with $\mathrm{CB}_{1}$ gene disruption are very similar to those seen in chronically stressed wild type mice. This suggests that $\mathrm{CB}_{1}$ deletion produces a chronic stress state that might contribute to altered responsiveness to environmental stimuli.

\section{ENHANCEMENT OF ANANDAMIDE SIGNALING THROUGH INHIBITION OF FAAH}

The first study demonstrating the impact of FAAH inhibitors on emotional behavior was published by Kathuria et al. (2003). They showed that the FAAH inhibitor URB597 robustly increases brain levels of anandamide but not 2-AG, and it has the anxiolytic effects of decreasing pup ultrasonic vocalizations and promoting exploration of the open section of the elevated O-maze. The authors concluded that their "results indicate that anandamide participates in the modulation of emotional states and point to fatty acid amide hydrolase inhibition as an innovative approach to anti-anxiety therapy." In a later publication, an overlapping group of authors demonstrated that URB597 decreases depression-like behaviors in both the forced swim and tail suspension models of depression, findings that "support a role for anandamide in mood regulation and point to fatty acid amide hydrolase as a previously uncharacterized target for antidepressant drugs" (Gobbi et al., 2005). Piomelli et al. (2006) concluded that URB597 does not evoke classical cannabinoid-like effects, but enhances the tonic actions of anandamide on a subset of $\mathrm{CB}_{1}$ receptors that are normally engaged in controlling emotion and pain. As such, FAAH inhibition in general and URB597 in particular show promise as treatments for anxiety and depression.

\section{Effects of FAAH inhibition in models of depression}

These early publications on the antidepressant- and anxiolyticlike effects of FAAH inhibition were supported by a series of 
Table 3 | Summary of studies investigating the effects of the FAAH inhibitor URB597 or genetic deletion of FAAH on anxiety-like and depression-like behavior in rodents.

\begin{tabular}{|c|c|c|c|c|c|c|}
\hline Authors & Animals & Drug & Doses and route & Test & Anxiety & Depression \\
\hline Kathuria et al. (2003) & Sprague-Dawley rats & URB597 & $0.1 \mathrm{mg} / \mathrm{kg}, \mathrm{IP}$ & Elevated 0 maze & $\downarrow$ & \\
\hline Kathuria et al. (2003) & $\begin{array}{l}\text { Sprague-Dawley rats } \\
\text { (pups) }\end{array}$ & URB597 & $0.1 \mathrm{mg} / \mathrm{kg}, \mathrm{IP}$ & $\begin{array}{l}\text { Isolation induced } \\
\text { USVs }\end{array}$ & $\downarrow$ & \\
\hline Gobbi et al. (2005) & Sprague-Dawley rats & URB597 & $0.1 \mathrm{mg} / \mathrm{kg}, \mathrm{IP}$ & Tail suspension test & & $\downarrow$ \\
\hline Gobbi et al. (2005) & Sprague-Dawley rats & URB597 & $0.1 \mathrm{mg} / \mathrm{kg}, \mathrm{IP}$ & Forced swim test & & $\downarrow$ \\
\hline Adamczyk et al. (2008) & Wistar rats & URB597 & $0.1-0.3 \mathrm{mg} / \mathrm{kg}, \mathrm{IP}$ & Forced swim test & & $\downarrow$ \\
\hline Bambico et al. (2010) & $\begin{array}{l}\text { FAAH KO mice } \\
\text { (C57BL6/6J) }\end{array}$ & $\mathrm{N} / \mathrm{A}$ & N/A & Tail suspension test & & $\downarrow$ \\
\hline Bambico et al. (2010) & $\begin{array}{l}\text { Mice, FAAH KO } \\
\text { (C57BL6/6J) }\end{array}$ & N/A & N/A & Forced swim test & & $\downarrow$ \\
\hline Realini et al. (2011) & $\begin{array}{l}\text { Sprague-Dawley rats } \\
\text { (females }+10 \text { days } \\
\text { THC treatment) }\end{array}$ & URB597 & $\begin{array}{l}0.3 \mathrm{mg} / \mathrm{kg} \text { IP (repeated } \\
30 \text { days) }\end{array}$ & Forced swim test & & $\downarrow$ \\
\hline Realini et al. (2011) & $\begin{array}{l}\text { Sprague-Dawley rats } \\
\text { (females }+10 \text { days } \\
\text { THC treatment) }\end{array}$ & URB597 & $\begin{array}{l}0.3 \mathrm{mg} / \mathrm{kg}, \text { IP (repeated } \\
30 \text { days) }\end{array}$ & $\begin{array}{l}\text { Sucrose } \\
\text { consumption }\end{array}$ & & $\downarrow$ \\
\hline Wright et al. (2010) & $\begin{array}{l}\text { Sprague-Dawley rats } \\
\text { (DFP treated) }\end{array}$ & URB597 & $3 \mathrm{mg} / \mathrm{kg}, \mathrm{IP}$ & Forced swim test & $=$ & \\
\hline Moreira et al. (2008) & C57BL/6N mice & URB597 & $10 \mathrm{mg} / \mathrm{kg}, \mathrm{IP}$ & EPM & $\downarrow$ & \\
\hline Patel and Hillard (2006) & ICR mice & URB597 & $0.1-0.3 \mathrm{mg} / \mathrm{kg}, \mathrm{IP}$ & EPM & $\downarrow$ & \\
\hline Lisboa et al. (2008) & Wistar rats & URB597 & $\begin{array}{l}0.01 \mathrm{nmol}, \mathrm{IC} \text { (dorsal } \\
\text { periaqueductal gray) }\end{array}$ & Vogel conflict test & $\downarrow$ & \\
\hline Rubino et al. (2008) & Sprague-Dawley rats & URB597 & $0.1 \mu \mathrm{g} / \mathrm{rat}$ & EPM & $\downarrow$ & \\
\hline Scherma et al. (2008) & Sprague-Dawley rats & URB597 & $0.1-0.3 \mathrm{mg} / \mathrm{kg}, \mathrm{IP}$ & Light-dark test & $\downarrow$ & \\
\hline Naderi et al. (2008) & NMRI mice & AM404 & $1-2 \mathrm{mg} / \mathrm{kg}, \mathrm{IP}$ & EPM & $\downarrow$ & \\
\hline Naderi et al. (2008) & NMRI mice & URB597 & $0.03-0.3 \mathrm{mg} / \mathrm{kg}, \mathrm{IP}$ & EPM & $=$ & \\
\hline Micale et al. (2009) & C57BL/6J mice & URB597 & $1 \mathrm{mg} / \mathrm{kg}, \mathrm{IP}$ & EPM & $\downarrow$ & \\
\hline Micale et al. (2009) & C57BL/6J mice & URB597 & $0.1-0.5 \mathrm{mg} / \mathrm{kg}, \mathrm{IP}$ & EPM & $=$ & \\
\hline Naidu et al. (2007) & C57BL/6J-ICR mice & URB597 & $0.3-1-3 \mathrm{mg} / \mathrm{kg}, \mathrm{IP}$ & EPM & $=$ & \\
\hline Naidu et al. (2007) & C57BL/6J-ICR mice & URB597 & $10 \mathrm{mg} / \mathrm{kg}, \mathrm{IP}$ & EPM & $=$ & \\
\hline Naidu et al. (2007) & C57BL/6J-ICR mice & URB597 & $0.1 \mathrm{mg} / \mathrm{kg}, \mathrm{IP}$ & Modified EPM & $\downarrow$ & \\
\hline Naidu et al. (2007) & $\begin{array}{l}\text { FAAH KO mice } \\
\text { (C57BL/6J) }\end{array}$ & N/A & N/A & EPM & $=$ & \\
\hline Naidu et al. (2007) & $\begin{array}{l}\text { FAAH KO mice } \\
\text { (C57BL/6J) }\end{array}$ & N/A & N/A & Tail suspension test & & $=$ \\
\hline Naidu et al. (2007) & C57BL/6J mice & URB597 & $0.1-10 \mathrm{mg} / \mathrm{kg}, \mathrm{IP}$ & Tail suspension test & & $=$ \\
\hline
\end{tabular}


Table 3 | Continued

\begin{tabular}{|c|c|c|c|c|c|c|}
\hline Authors & Animals & Drug & Doses and route & Test & Anxiety & Depression \\
\hline Naidu et al. (2007) & $\begin{array}{l}\text { FAAH KO mice } \\
\text { (C57BL/6J) }\end{array}$ & $\mathrm{N} / \mathrm{A}$ & $\mathrm{N} / \mathrm{A}$ & $\begin{array}{l}\text { Modified tail } \\
\text { suspension test }\end{array}$ & & $\downarrow$ \\
\hline Naidu et al. (2007) & C57BL/6J mice & URB597 & $0.1 \mathrm{mg} / \mathrm{kg}, \mathrm{IP}$ & $\begin{array}{l}\text { Modified tail } \\
\text { suspension test }\end{array}$ & & $\downarrow$ \\
\hline Seillier and Giuffrida (2011) & Wistar rats & URB597 & $0.1,0.3,1 \mathrm{mg} / \mathrm{kg}, \mathrm{IP}$ & EPM & $=$ & \\
\hline Haller et al. (2009) & Sprague-Dawley rats & URB597 & $0.1-0.3 \mathrm{mg} / \mathrm{kg}, \mathrm{IP}$ & $\begin{array}{l}\text { EPM (low } \\
\text { aversiveness) }\end{array}$ & $=$ & \\
\hline Haller et al. (2009) & Sprague-Dawley rats & URB597 & $0.1-0.3 \mathrm{mg} / \mathrm{kg}, \mathrm{IP}$ & $\begin{array}{l}\text { EPM (high } \\
\text { aversiveness) }\end{array}$ & $\downarrow$ & \\
\hline
\end{tabular}

EPM, elevated plus-maze. For effects in models of anxiety and depression, $\downarrow$ indicates impairment; $\uparrow$ indicates enhancement; $=$ indicates no effect.

subsequent findings (see Table 3 ). In models of depression, systemic, and i.c.v. treatments with URB597, as well as genetic deletion of FAAH, decreased immobility in the forced swim, and tail suspension tests (Adamczyk et al., 2008; Bambico et al., 2010; Manna and Jain, 2011; Umathe et al., 2011), while systemic URB597 administration counteracted the deleterious effects of chronic mild stress (Bortolato et al., 2007), abolished estrogen deficiency-induced depression in female rats (Hill et al., 2007), and reversed depression-like symptoms induced by THC in adolescent female rats (Realini et al., 2011). In the forced swim test, URB597 reversed depression-like effects in rats 29 days (but not 8 days) after exposure to diisopropylfluorophosphate (Wright et al., 2010). The $\mathrm{CB}_{1}$ dependence of these effects was verified in most of the cited studies, confirming that they were due to FAAH-induced enhancement of anandamide signaling at $\mathrm{CB}_{1}$ receptors. The role of anandamide in these antidepressant effects is further supported by the finding that the anandamide-transport inhibitor AM404 exerted similar effects in some studies (Adamczyk et al., 2008; Umathe et al., 2011).

However, conflicting findings also exist. URB597 had no effect when infused into the dentate gyrus of the hippocampus, despite the fact that the direct $\mathrm{CB}_{1}$ agonist HU-210 administered in the same way produced antidepressant effects in the forced swim test (McLaughlin et al., 2007). This finding suggests that depressionlike behavior is affected by anandamide-independent cannabinoid mechanisms in certain cases and in certain brain areas. Naidu et al. (2007) found that the FAAH inhibitors URB597 and OL-135 only affected depression-like behavior in the forced swim and tail suspension tests when the tests were performed under modified lighting conditions and when large sample sizes were used.

\section{Effects of FAAH inhibition in models of anxiety}

URB597 decreased anxiety in the elevated plus-maze when given systemically (Patel and Hillard, 2006; Moise et al., 2008; Moreira et al., 2008) or when injected into the medial prefrontal cortex or dorsolateral periaqueductal gray, two regions that play important roles in the control of anxiety (Lisboa et al., 2008; Rubino et al., 2008).URB597 also abolished the anxiogenic response measured in the elevated plus-maze during withdrawal after an acute administration of alcohol (Cippitelli et al., 2008). Anxiolytic effects of URB597 were also shown in the Vogel conflict test (injected into dorsolateral periaqueductal gray; Lisboa et al., 2008) and light-dark test (injected systemically; Scherma et al.,
2008). Like FAAH inhibition, anandamide-transport inhibition decreased anxiety (Lisboa et al., 2008; Naderi et al., 2008), suggesting that the enhancement of endogenous anandamide release decreases anxiety irrespective of the method by which it was achieved. Mice with FAAH genetically deleted showed reduced emotionality in both the social interaction test and the open field test, and these differences were abolished by treatment with rimonabant (Cassano et al., 2011).

However, there are also a number of conflicting findings regarding the effects of FAAH inhibition on anxiety (see Table 3). Some of these contradictions can be considered negligible. For example, acute or chronic treatment with URB597 doses that were very effective at producing anxiolytic effects in other studies $(0.1$, and $0.5 \mathrm{mg} / \mathrm{kg}$ ) did not affect anxiety in the elevated plus-maze in the study by Micale et al. (2009), but a higher dose $(1 \mathrm{mg} / \mathrm{kg})$ did. In another study, URB597 had no effect on anxiety in the mouse defense test battery, but had an anxiolytic effect in a more conventional model, the elevated plus-maze (Moise et al., 2008). To a certain extent, the findings by Scherma et al. (2008) are also at variance with the assumption that enhanced anandamide signaling decreases anxiety. Although these authors did show an anxiolytic effect with URB597, co-administration of anandamide reversed this effect. This finding might be explained by the fact that FAAH inhibition selectively affects areas where endogenous anandamide is being released, while exogenous administration of anandamide (the effects of which are prolonged by FAAH inhibition) would affect cannabinoid receptors throughout the brain.

Harder to explain are the findings of Naderi et al. (2008), Naidu et al. (2007), and Seillier and Giuffrida (2011), who failed to detect any anxiolytic effect of URB597 in the elevated plus-maze (i.e., the test in which FAAH inhibition was first found to be anxiolytic). Haller et al. (2009) reported that URB597 did not decrease anxiety when the elevated plus-maze test was performed under mildly aversive conditions (e.g., in a familiar room or under low light). In contrast, the benzodiazepine anxiolytic chlordiazepoxide decreased anxiety under all conditions. In the case of genetic deletion of FAAH, mutant mice showed evidence of decreased anxiety relative to wild type mice under both bright and dim lighting conditions in the social interaction and open field tests; but, when the mutant mice received rimonabant under dim lighting conditions in the open field test (i.e., under less aversive conditions), their behavior suggested hypersensitivity to anxiogenic effects of $\mathrm{CB}_{1}$ blockade (Cassano et al., 2011). After carefully reviewing published 
methodological details and personally interviewing the authors of earlier publications, Haller et al. (2009) suggested that success or failure in detecting anxiolytic effects with URB597 was largely explained by the degree of aversiveness of the testing environment in particular studies. Since various testing conditions can differentially model specific forms of anxiety, these findings suggest that FAAH inhibition (and its functional equivalent, anandamidetransport inhibition) might blunt the anxiogenic effects of stressful environmental stimuli rather than producing an overall reduction in anxiety.

\section{CONCLUSION - ENDOCANNABINOID SIGNALING AND EMOTIONAL BEHAVIOR}

Cannabinoid signaling appears to decrease depression-like and anxiety-like behaviors in laboratory models. These effects were observed using a variety of means to affect cannabinoid signaling, a variety of animal models, and a variety of species. The reasons for discrepancies are multiple, but an increasing number of publications suggest that the emotional effects of enhanced endocannabinoid signaling largely depend on environmental influences. These findings suggest that the anxiolytic effects, and possibly the antidepressant effects, of endocannabinoid signaling are enhanced under aversive conditions, which strengthens, rather than weakens, the putative usefulness of medications that enhance endocannabinoid signaling in the treatment of emotional disorders.

\section{CONTEXT DEPENDENCE OF ENDOCANNABINOID MODULATION OF COGNITIVE AND EMOTIONAL BEHAVIOR BRAIN FUNCTIONS AND ASSUMPTIONS FOR BEHAVIOR}

Uniquely, endocannabinoids signal "backward": they are released from the post-synaptic membrane and inhibit the synaptic neurotransmission that triggered their release (Wilson and Nicoll, 2001). Although a certain, probably low, level of tonic activation cannot be excluded, the endocannabinoid signal occurs phasically on demand, i.e., when the intensity of anterograde synaptic communication reaches certain levels (Di Marzo et al., 1999; Marsicano et al., 2003; Lutz, 2004; Adermark and Lovinger, 2007). As such, the main role of endocannabinoid signaling appears to be the blockade of excessive neuronal activation. The $\mathrm{CB}_{1}$ receptor is strongly expressed in limbic structures (Herkenham et al., 1991), suggesting that cannabinoid signaling has a particularly important role in the control of neuronal responses induced by environmental challenges that often involve an emotional dimension. As brain anandamide levels are strongly increased by aversive stimuli (Walker et al., 1999; Kirkham et al., 2002; Marsicano et al., 2002; Hohmann et al., 2005), one can hypothesize that the activity dependent release of endocannabinoids serves as a feedback mechanism that reduces the amplitude of challengeinduced neuronal excitations (Gerdeman and Lovinger, 2001; Adermark and Lovinger, 2007; Straiker and Mackie, 2009). This mechanism may be one that explains the strong impact of environmental conditions on the behavioral consequences of FAAH inhibition. Particularly, enhanced dampening of aversion-induced neuronal activations may lessen the behavioral impact of aversive stimuli.

In most cases the cognitive and emotional consequences of FAAH inhibition have been demonstrated to be $\mathrm{CB}_{1}$-mediated.
The broad effects of anandamide signaling may offer an alternative explanation for the impact of environmental conditions on the behavioral consequences of FAAH inhibition. $\mathrm{CB}_{1}$ receptors occur on GABAergic and glutamatergic synapses, and activation of these receptors can inhibit the release of several neurotransmitters, including glycine, acetylcholine, norepinephrine, dopamine, serotonin, and cholecystokinin (Gifford and Ashby, 1996; Ishac et al., 1996; Cadogan et al., 1997; Katona et al., 1999, 2001; Nakazi et al., 2000; Beinfeld and Connolly, 2001; Hájos and Freund, 2002; Fernández-Ruiz et al., 2010). Thus, endocannabinoids affect the function of many neurotransmitter systems, some of which play opposing roles. For example, glutamatergic mechanisms appear to promote anxiety while GABAergic mechanisms appear to inhibit it (Millan, 2003). This diversity of cannabinoid roles and the complexity of task-dependent activation of neuronal circuits may inherently lead to the effects of endocannabinoid activation being strongly dependent on environmental conditions.

Presumably, each environmental challenge and behavioral response is bound to the activation of particular neuronal circuits. The effects of cannabinoid signaling probably depend on the ratio, brain location, and neurochemical nature of those neurons that express cannabinoid receptors and are activated in the particular situation. A small change in the environment might recruit new neurons in the situation-dependent circuit, changing the share, location, and neurochemical nature of the cannabinoid-controlled synapses that were activated. Thus, each effect of cannabinoids would be specific to the situation.

The hypothesis presented here has two parts: that cannabinoid signaling has an important role in dampening excessive neuronal responses induced by environmental challenges that often involve an emotional dimension, and that the function of endocannabinoid neuronal circuits is situation-dependent. Endocannabinoid signaling is activated when there is a relatively high level of synaptic activity, as would be triggered by environmental challenges that require prompt behavioral responses. Retrograde signaling by cannabinoids would affect only those neurons that: (1) are highly activated by the perception or interpretation of the challenging information and by the behavioral response; and (2) also express $\mathrm{CB}_{1}$ receptors on their axon terminals. These conditions are likely to be met by neurons that have opposing roles overall (e.g., glutamatergic and GABAergic neurons) or have wide ranging behavioral effects (e.g., monoaminergic neurotransmission). As a result, cannabinoids selectively affect a mosaic of widely heterogeneous neurons that may have convergent, divergent, or independent effects on the development of the behavioral response, and leave many neurons unaffected, or affected only indirectly. Interfering with such a complex regulatory process naturally leads to complex and situation-dependent effects. Under such conditions, the relative consistency of available findings may be due to the fact that scientific studies are highly standardized. Even small deviations from experimental protocols (e.g., directing the light on the tail of rats in the tail suspension test; Naidu et al., 2007) may bring about surprising findings. More surprising findings can be expected after more dramatic changes in experimental conditions, for example by varying the aversiveness of environmental conditions (Haller et al., 2009). 
One possible argument against this hypothesis is that anandamide may not be directly involved in $\mathrm{CB}_{1}$-mediated retrograde endocannabinoid signaling, because the post-synaptic localization of its synthesizing enzymes is at variance with the presynaptic localization of the $\mathrm{CB}_{1}$ receptor (Katona and Freund, 2008). One has to note, however, that cannabinoids were shown to affect extra-synaptic (volumetric) neurotransmission (Lau and Schloss, 2008; Morgese et al., 2009), and endocannabinoids, especially anandamide, are able to exert effects via the putative $\mathrm{CB}_{3}$ (non- $\mathrm{CB}_{1} /$ non- $\mathrm{CB}_{2}$ ) cannabinoid receptor (De Petrocellis and Di Marzo, 2010). One also has to note that discrepancies between functional and morphological findings may be fairly common in the case of cannabinoid signaling (see e.g., Kawamura et al., 2006).

\section{CONCLUSION AND PRACTICAL IMPLICATIONS}

Conflicting findings are not rare in behavioral pharmacology. Yet, the enhancement or blockade of endocannabinoid signaling has provided inconsistent findings even within the same laboratory; moreover, deliberate changes in environmental conditions have resulted in marked changes in the effects of the same manipulations within the same series of experiments. Taken together, the findings reviewed here raise the possibility that endocannabinoid signaling may change the impact of environmental influences on

\section{REFERENCES}

Acheson, S. K., Moore, N. L. T., Kuhn, C. M., Wilson, W. A., and Swartzwelder, H. S. (2011). The synthetic cannabinoid WIN 55212-2 differentially modulates thigmotaxis but not spatial learning in adolescent and adult animals. Neurosci. Lett. 487, 411-414.

Adamczyk, P., Golda, A., McCreary, A. C., Filip, M., and Przegalinski, E. (2008). Activation of endocannabinoid transmission induces antidepressant-like effects in rats. $J$. Physiol. Pharmacol. 59, 217-228.

Adermark, L., and Lovinger, D. M. (2007). Retrograde endocannabinoid signaling at striatal synapses requires a regulated postsynaptic release step. Proc. Natl. Acad. Sci. U.S.A. 104, 20564-20569.

Ainge, J. A., Heron-Maxwell, C., Theofilas, P., Wright, P., de Hoz, L., and Wood, E. R. (2006). The role of the hippocampus in object recognition in rats: examination of the influence of task parameters and lesion size. Behav. Brain Res. 167, 183-195.

Bambico, F. R., Cassano, T., DominguezLopez, S., Katz, N., Walker, C. D., Piomelli, D., and Gobbi, G. (2010). Genetic deletion of fatty acid amide hydrolase alters emotional behavior and serotonergic transmission in the dorsal raphe, prefrontal cortex, and hippocampus. Neuropsychopharmacology 35, 2083-2100.

Bambico, F. R., Duranti, A., Tontini, A., Tarzia, G., and Gobbi, G. (2009).
Endocannabinoids in the treatment of mood disorders: evidence from animal models. Curr. Pharm. Des. 15, 1623-1646.

Barna, I., Soproni, K., Arszovszki, A., Csabai, K., and Haller, J. (2007). WIN-55,212-2 chronically implanted into the CA3 region of the dorsal hippocampus impairs learning: a novel method for studying chronic, brain-area-specific effects of cannabinoids. Behav. Pharmacol. $18,515-520$.

Beinfeld, M. C., and Connolly, K. (2001). Activation of CB1 cannabinoid receptors in rat hippocampal slices inhibits potassium-evoked cholecystokinin release, a possible mechanism contributing to the spatial memory defects produced by cannabinoids. Neurosci. Lett. 301, 69-71.

Bitencourt, R. M., Pamplona, F. A., and Takahashi, R. N. (2008). Facilitation of contextual fear memory extinction and anti-anxiogenic effects of AM404 and cannabidiol in conditioned rats. Eur. Neuropsychopharmacol. 18, 849-859. Kim, J. H., Arguello, O., Duranti, A., Tontini, A., Mor, M., Tarzia, G., and Piomelli, D. (2007). Antidepressant-like activity of the fatty acid amide hydrolase inhibitor URB597 in a rat model of chronic mild stress. Biol. Psychiatry 62, 1103-1110.

Cadogan, A. K., Alexander, S. P., Boyd, E. A., and Kendall, D. A. (1997).
Bortolato, M., Mangieri, R. A., Fu, J.,

behavior rather than affecting one or another specific behavior. This assumption may be especially valid for emotional behaviors, but it may indirectly affect findings obtained in tests where emotions are not the focus, such as learning and memory. Further research in this respect appears warranted.

From a practical point of view, the assumption formulated above may not necessarily invalidate cannabinoid neurotransmission as a pharmaceutical target. Altered responses to environmental stimuli are at the core of emotional disorders, and also appertain to disorders related to learning and memory. Thus, the ability of cannabinoid-related treatments to modulate the impact of challenging environmental conditions on emotional and cognitive behavior could be a productive focus for medications development.

\section{ACKNOWLEDGMENTS}

This study was supported in part by the Intramural Research Program of the National Institute on Drug Abuse, National Institutes of Health, Department of Health and Human Services, Baltimore, MD, USA; by the Institute of Experimental Medicine, Budapest, Hungary and by the Division of Geriatric Medicine and Gerontology, Johns Hopkins University School of Medicine, Baltimore, MD, USA.

Influence of cannabinoids on electrically evoked dopamine release and cyclic AMP generation in the rat striatum. J. Neurochem. 69, 1131-1137.

Campolongo, P., Roozendaal, B., Trezza, V., Cuomo, V., Astarita, G., Fu, J., McGaugh, J. L., and Piomelli, D. (2009a). Fat-induced satiety factor oleoylethanolamide enhances memory consolidation. Proc. Natl. Acad. Sci. U.S.A. 106, 8027-8031.

Campolongo, P., Roozendaal, B., Trezza, V., Hauer, D., Schelling, G., McGaugh, J. L., and Cuomo, V. (2009b). Endocannabinoids in the rat basolateral amygdala enhance memory consolidation and enable glucocorticoid modulation of memory. Proc. Natl. Acad. Sci. U.S.A. 106, 4888-4893.

Cannich, A., Wotjak, C. T., Kamprath, K., Hermann, H., Lutz, B., and Marsicano, G. (2004). CB1 cannabinoid receptors modulate kinase and phosphatase activity during extinction of conditioned fear in mice. Learn. Mem. 11, 625-632.

Cassano, T., Gaetani, S., Macheda, T., Laconca, L., Romano, A., Morgese, M. G., Cimmino, C. S., Chiarotti, F., Bambico, F. R., Gobbi, G., Cuomo, V., and Piomelli, D. (2011). Evaluation of the emotional phenotype and serotonergic neurotransmission of fatty acid amide hydrolase-deficient mice. Psychopharmacology (Berl.) 214, 465-476.

Castellano, C., Cabib, S., Palmisano, A., Di Marzo, V., and Puglisi-Allegra, S.
(1997). The effects of anandamide on memory consolidation in involve both D1 and D2 dopamine receptors. Behav. Pharmacol. 8, 707-712.

Castellano, C., Ventura, R., Cabib, S., and Puglisi-Allegra, S. (1999). Strain-dependent effects of anandamide on memory consolidation in are antagonized by naltrexone. Behav. Pharmacol. 10, 453-457.

Chhatwal, J. P., Davis, M., Maguschak, K. A., and Ressler, K. J. (2005). Enhancing cannabinoid neurotransmission augments the extinction of conditioned fear. Neuropsychopharmacology 30, 516-524.

Ciccocioppo, R., Antonelli, L., Biondini, M., Perfumi, M., Pompei, P., and Massi, M. (2002). Memory impairment following combined exposure to delta-tetrahydrocannabinol and ethanol in rats. Eur. J. Pharmacol. 449, 245-252.

Cippitelli, A., Cannella, N., Braconi, S., Duranti, A., Tontini, A., Bilbao, A., Defonseca, F. R., Piomelli, D., and Ciccocioppo, R. (2008). Increase of brain endocannabinoid anandamide levels by FAAH inhibition and alcohol abuse behaviours in the rat. Psychopharmacology (Berl.) 198, 449-460.

Costanzi, M., Battaglia, M., RossiArnaud, C., Cestari, V., and Castellano, C. (2004). Effects of anandamide and morphine combinations on memory consolidation in cd1 mice: involvement of dopaminergic mechanisms. Neurobiol. Learn. Mem. 81, 144-149. 
DaSilva, G. E., and Takahashi, R. N. (2002). SR 141716A prevents delta 9tetrahydrocannabinol-induced spatial learning deficit in a Morris-type water maze in mice. Prog. Neuropsychopharmacol. Biol. Psychiatry 26, 321-325.

De Petrocellis, L., and Di Marzo, V. (2010). Non-CB1, non-CB2 receptors for endocannabinoids, plant cannabinoids, and synthetic cannabimimetics: focus on Gprotein-coupled receptors and transient receptor potential channels. J. Neuroimmune Pharmacol. 5, 103-121.

Deadwyler, S. A., Bunn, T., and Hampson, R. E. (1996). Hippocampal ensemble activity during spatial delayed-nonmatch-to-sample performance in rats. J. Neurosci.16, 354-372.

Deadwyler, S. A., Goonawardena, A. V., and Hampson, R. E. (2007). Short-term memory is modulated by the spontaneous release of endocannabinoids: evidence from hippocampal population codes. Behav. Pharmacol. 18, 571-580.

Deadwyler, S. A., and Hampson, R. E. (2008). Endocannabinoids modulate encoding of sequential memory in the rat hippocampus. Psychopharmacology (Berl.) 198, 577-586.

Degroot, A., and Nomikos, G. G. (2004). Genetic deletion and pharmacological blockade of CB1 receptors modulates anxiety in the shock-probe burying test. Eur. J. Neurosci. 20, 1059-1064.

Di Marzo, V., Breivogel, C. S., Tao, Q., Bridgen, D. T., Razdan, R. K., Zimmer, A. M., Zimmer, A., and Martin, B. R. (2000). Levels, metabolism, and pharmacological activity of anandamide in CB1 cannabinoid receptor knockout mice: evidence for non-CB1, non-CB receptormediated actions of anandamide in mouse brain. J. Neurochem. 75, 2434-2444.

Di Marzo, V., De Petrocellis, L., Bisogno, T., and Melck, D. (1999). Metabolism of anandamide and 2arachidonoylglycerol: an historical overview and some recent developments. Lipids 34(Suppl.), S319S325.

Diana, G., Malloni, M., and Pieri, M. (2003). Effects of the synthetic cannabinoid nabilone on spatial learning and hippocampal neurotransmission. Pharmacol. Biochem. Behav. 75, 585-591.

Egashira, N., Ishigami, N., Mishima, K., Iwasaki, K., Oishi, R., and
Fujiwara, M. (2008). Delta9tetrahydrocannabinol-induced cognitive deficits are reversed by olanzapine but not haloperidol in rats. Prog. Neuropsychopharmacol. Biol. Psychiatry 32, 499-506.

Egashira, N., Mishima, K., Iwasaki, K., and Fujiwara, M. (2002). Intracerebral microinjections of delta 9tetrahydrocannabinol: search for the impairment of spatial memory in the eight-arm radial maze in rats. Brain Res. 952, 239-245.

Fegley, D., Gaetani, S., Duranti, A., Tontini, A., Mor, M., Tarzia, G., and Piomelli, D. (2005). Characterization of the fatty acid amide hydrolase inhibitor cyclohexyl carbamic acid 3 -carbamoyl-biphenyl3-yl ester (URB597): effects on anandamide and oleoylethanolamide deactivation. J. Pharmacol. Exp. Ther. 313, 352-358.

Fernández-Ruiz, J., Hernández, M., and Ramos, J. A. (2010). Cannabinoiddopamine interaction in the pathophysiology and treatment of CNS disorders. CNS Neurosci. Ther. 16, e72-e91.

Ferrari, F., Ottani, A., Vivoli, R., and Giuliani, D. (1999). Learning impairment produced in rats by the cannabinoid agonist HU 210 in a water-maze task. Pharmacol. Biochem. Behav. 64, 555-561.

Fride, E., Suris, R., Weidenfeld, J., and Mechoulam, R. (2005). Differential response to acute and repeated stress in cannabinoid CB1 receptor knockout newborn and adult mice. Behav. Pharmacol. 16, 431-440.

Ganon-Elazar, E., and Akirav, I. (2009). Cannabinoid receptor activation in the basolateral amygdala blocks the effects of stress on the conditioning and extinction of inhibitory avoidance. J. Neurosci. 29, 11078-11088.

Gerdeman, G., and Lovinger, D. M. (2001). CB1 cannabinoid receptor inhibits synaptic release of glutamate in rat dorsolateral striatum. $J$. Neurophysiol. 85, 468-471.

Gifford, A. N., and Ashby, C. R. Jr. (1996). Electrically evoked acetylcholine release from hippocampal slices is inhibited by the cannabinoid receptor agonist, WIN 55212-2, and is potentiated by the cannabinoid antagonist, SR 141716A. J. Pharmacol. Exp. Ther. 277, 1431-1436.

Gobbi, G., Bambico, F. R., Mangieri, R., Bortolato, M., Campolongo, P., Solinas, M., Cassano, T., Morgese, M. G., Debonnel, G., Duranti, A., Tontini, A., Tarzia, G., Mor, M., Trezza, V., Goldberg, S. R., Cuomo, V., and Piomelli, D. (2005). Antidepressantlike activity and modulation of brain monoaminergic transmission by blockade of anandamide hydrolysis. Proc. Natl. Acad. Sci. U.S.A. 102, 18620-18625.

Goonawardena, A. V., Robinson, L. Hampson, R. E., and Riedel, G. (2010). Cannabinoid and cholinergic systems interact during performance of a short-term memory task in the rat. Learn. Mem. 28, 502-211.

Griebel, G., Stemmelin, J., and Scatton, B. (2005). Effects of the cannabinoid CB1 receptor antagonist rimonabant in models of emotional reactivity in rodents. Biol. Psychiatry 57, 261-267.

Hájos, N., and Freund, T. F. (2002). Pharmacological separation of cannabinoid sensitive receptors on hippocampal excitatory and inhibitory fibers. Neuropharmacology 43, 503-510.

Haller, J., Bakos, N., Szirmay, M., Ledent, C., and Freund, T. F. (2002). The effects of genetic and pharmacological blockade of the CB1 cannabinoid receptor on anxiety. Eur. J. Neurosci. 16, 1395-1398.

Haller, J., Barna, I., Barsvari, B., Gyimesi Pelczer, K., Yasar, S., Panlilio, L. V., and Goldberg, S. (2009). Interactions between environmental aversiveness and the anxiolytic effects of enhanced cannabinoid signaling by FAAH inhibition in rats. Psychopharmacology (Berl.) 204, 607-616.

Haller, J., Mátyás, F., Soproni, K., Varga, B., Barsy, B., Németh, B., Mikics, E., Freund, T. F., and Hájos, N. (2007). Correlated species differences in the effects of cannabinoid ligands on anxiety and on GABAergic and glutamatergic synaptic transmission. Eur. J. Neurosci. 25, 2445-2456.

Haller, J., Varga, B., Ledent, C., Barna, I. and Freund, T. F. (2004a). Contextdependent effects of CB1 cannabinoid gene disruption on anxiety-like and social behaviour in mice. Eur. J. Neurosci. 19, 1906-1912.

Haller, J., Varga, B., Ledent, C., and Freund, T. F. (2004b). CB1 cannabinoid receptors mediate anxiolytic effects: convergent genetic and pharmacological evidence with CB1specific agents. Behav. Pharmacol. 15, 299-304.

Hampson, R. E., and Deadwyler, S. A. (2000). Cannabinoids reveal the necessity of hippocampal neural encoding for short-term memory in rats. J. Neurosci. 20, 8932-8942.

Harloe, J. P., Thorpe, A. J., and Lichtman, A. H. (2008). Differential endocannabinoid regulation of extinction in appetitive and aversive
Barnes maze tasks. Learn. Mem. 15, 806-809.

Herkenham, M., Lynn, A. B., Johnson, M. R., Melvin, L. S., de Costa, B. R., and Rice, K. C. (1991). Characterization and localization of cannabinoid receptors in rat brain: a quantitative in vitro autoradiographic study. $J$. Neurosci. 11, 563-583

Heuer, E., and Bachevalier, J. (2011). Effects of selective neonatal hippocampal lesions on tests of object and spatial recognition memory in monkeys. Behav. Neurosci. 125, 137-149.

Heyser, C. J., Hampson, R. E., and Deadwyler, S. A. (1993). Effects of delta9-tetrahydrocannabinol on delayed match to sample performance in rats: alterations in short-term memory associated with changes in task specific firing of hippocampal cells. J. Pharmacol. Exp. Ther. 264 294-307.

Hill, M. N., Froese, L. M., Morrish, A. C., Sun, J. C., and Floresco, S. B. (2006). Alterations in behavioral flexibility by cannabinoid CB1 receptor agonists and antagonists. Psychopharmacology (Berl.) 187, 245-259.

Hill, M. N., Hillard, C. J., and McEwen, B. S. (2011). Alterations in corticolimbic dendritic morphology and emotional behavior in cannabinoid CB1 receptor-deficient parallel the effects of chronic stress. Cereb. Cortex 21, 2056-2064.

Hill, M. N., Karacabeyli, E. S., and Gorzalka, B. B. (2007). Estrogen recruits the endocannabinoid system to modulate emotionality. Psychoneuroendocrinology 32, 350-357.

Hohmann, A. G., Suplita, R. L., Bolton, N. M., Neely, M. H., Fegley, D., Mangieri, R., Krey, J. F., Walker, J. M., Holmes, P. V., Crystal, J. D., Duranti, A., Tontini, A., Mor, M., Tarzia, G., and Piomelli, D. (2005). An endocannabinoid mechanism for stress-induced analgesia. Nature 435, 1108-1112.

Hölter, S. M., Kallnik, M., Wurst, W., Marsicano, G., Lutz, B., and Wotjak, C. T. (2005). Cannabinoid CB1 receptor is dispensable for memory extinction in an appetitivelymotivated learning task. Eur. J. Pharmacol. 510, 69-74.

Houchi, H., Babovic, D., Pierrefiche O., Ledent, C., Daoust, M., and Naassila, M. (2005). CB1 receptor knockout display reduced ethanol-induced conditioned place preference and increased striatal dopamine D2 receptors. Neuropsychopharmacology 30 , 339-349. 
Inui, K., Egashira, N., Mishima, K., Yano, A., Matsumoto, Y., Hasebe, N., Abe, K., Hayakawa, K., Ikeda, T., Iwasaki, K., and Fujiwara, M. (2004). The serotonin1A receptor agonist 8-OHDPAT reverses delta 9-tetrahydrocannabinol-induced impairment of spatial memory and reduction of acetylcholine release in the dorsal hippocampus in rats. Neurotox. Res. 6, 153-158.

Isaacson, R. L., and Wickelgren, W. O. (1962). Hippocampal ablation and passive avoidance. Science 138, 1104-1106.

Ishac, E. J., Jiang, L., Lake, K. D., Varga, K., Abood, M. E., and Kunos, G. (1996). Inhibition of exocytotic noradrenaline release by presynaptic cannabinoid CB1 receptors on peripheral sympathetic nerves. $\mathrm{Br}$. J. Pharmacol. 118, 2023-2028.

Jacob, W., Yassouridis, A., Marsicano, G., Monory, K., Lutz, B., and Wotjak, C. T. (2009). Endocannabinoids render exploratory behaviour largely independent of the test aversiveness: role of glutamatergic transmission. Genes Brain Behav. 8, 685-698.

Jentsch, J. D., Verrico, C. D., Le, D., and Roth, R. H. (1998). Repeated exposure to delta-9tetrahydrocannabinol reduces prefrontal cortical dopamine metabolism in the rat. Neurosci. Lett. 246, 169-172.

Kamprath, K., Marsicano, G., Tang, J., Monory, K., Bisogno, T., Di Marzo, V., Lutz, B., and Wotjak, C. T. (2006). Cannabinoid CB1 receptor mediates fear extinction via habituation-like processes. J. $\mathrm{Neu}$ rosci. 26, 6677-6686.

Kathuria, S., Gaetani, S., Fegley, D., Valiño, F., Duranti, A., Tontini, A., Mor, M., Tarzia, G., La Rana, G., Calignano, A., Giustino, A., Tattoli, M., Palmery, M., Cuomo, V., and Piomelli, D. (2003). Modulation of anxiety through blockade of anandamide hydrolysis. Nat. Med. 9 , 76-81.

Katona, I., and Freund, T. F. (2008). Endocannabinoid signaling as a synaptic circuit breaker in neurological disease. Nat. Med. 14, 923-930.

Katona, I., Rancz, E. A., Acsady, L., Ledent, C., Mackie, K., Hajos, N., and Freund, T. F. (2001). Distribution of CB1 cannabinoid receptors in the amygdala and their role in the control of GABAergic transmission. J. Neurosci. 21, 9506-9518.

Katona, I., Sperlágh, B., Sík, A., Käfalvi, A., Vizi, E. S., Mackie, K., and Freund, T. F. (1999). Presynaptically located CB1 cannabinoid receptors regulate GABA release from axon terminals of specific hippocampal interneurons. J. Neurosci. 19, 4544-4558.

Kawamura, Y., Fukaya, M., Maejima, T., Yoshida, T., Miura, E., Watanabe, M., Ohno-Shosaku, T., and Kano, M. (2006). The CB1 cannabinoid receptor is the major cannabinoid receptor at excitatory presynaptic sites in the hippocampus and cerebellum. $J$. Neurosci. 26, 2991-3001.

Kirkham, T. C., Williams, C. M., Fezza, F., and Di Marzo, V. (2002). Endocannabinoid levels in rat limbic forebrain and hypothalamus in relation to fasting, feeding and satiation: stimulation of eating by 2arachidonoyl glycerol. Br. J. Pharmacol. 136, 550-557.

Lau, T., and Schloss, P. (2008). The cannabinoid CB1 receptor is expressed on serotonergic and dopaminergic neurons. Eur. J. Pharmacol. 578, 137-141.

Lichtman, A. H. (2000). SR 141716A enhances spatial memory as assessed in a radial-arm maze task in rats. Eur. J. Pharmacol. 404, 175-179.

Lichtman, A. H., Dimen, K. R., and Martin, B. R. (1995). Systemic or intrahippocampal cannabinoid administration impairs spatial memory in rats. Psychopharmacology (Berl.) 119, 282-290.

Lichtman, A. H., and Martin, B. R. (1996). Delta 9-tetrahydrocannabinol impairs spatial memory through a cannabinoid receptor mechanism. Psychopharmacology (Berl.) 126, 125-131.

Lisboa, S. F., Resstel, L. B. M., Aguiar, D. C., and Guimarães, F. S. (2008). Activation of cannabinoid $\mathrm{CB} 1$ receptors in the dorsolateral periaqueductal gray induces anxiolytic effects in rats submitted to the Vogel conflict test. Eur. J. Pharmacol. 593, 73-78.

Long, J. Z., Li, W., Booker, L., Burston, J. J., Kinsey, S. G., Schlosburg, J. E., Pavón, F. J., Serrano, A. M., Selley, D. E., Parsons, L. H., Lichtman, A. H., and Cravatt, B. F. (2009). Selective blockade of 2-arachidonoylglycerol hydrolysis produces cannabinoid behavioral effects. Nat. Chem. Biol. 5, 37-44.

Lutz, B. (2004). On-demand activation of the endocannabinoid system in the control of neuronal excitability and epileptiform seizures. Biochem. Pharmacol. 68, 1691-1698.

Maccarrone, M., Valverde, O., Barbaccia, M. L., Castañé, A., Maldonado, R., Ledent, C., Parmentier, M., and Finazzi-Agrò, A. (2002). Age-related changes of anandamide metabolism in CB1 cannabinoid receptor knockout mice: correlation with behaviour. Eur. J. Neurosci. 15, 1178-1186.
Mallet, P. E., and Beninger, R. J. (1998). The cannabinoid $\mathrm{CB} 1$ receptor antagonist SR141716A attenuates the memory impairment produced by delta9-tetrahydrocannabinol or anandamide. Psychopharmacology (Berl.) 140, 11-19.

Manna, S. S. S., and Jain, N. S. (2011). Involvement of endocannabinoids in antidepressant and anti-compulsive effect of fluoxetine in mice. Behav. Brain Res. 223 125-134.

Marsicano, G., Goodenough, S. Monory, K., Hermann, H., Eder, M., Cannich, A., Azad, S. C., Cascio, M. G., Gutiérrez, S. O., van der Stelt, M., López-Rodriguez, M. L., Casanova, E., Schütz, G., Zieglgänsberger, W., Di Marzo, V., Behl, C., and Lutz, B. (2003). CB1 cannabinoid receptors and on-demand defense against excitotoxicity. Science 302, 84-88.

Marsicano, G., Wotjak, C. T., Azad, S. C. Bisogno, T., Rammes, G., Cascio, M. G., Hermann, H., Tang, J., Hofmann, C., Zieglgänsberger, W., Di Marzo, V., and Lutz, B. (2002). The endogenous cannabinoid system controls extinction of aversive memories. Nature 418, 530-534.

Martin, M., Ledent, C., Parmentier, M., Maldonado, R., and Valverde, O. (2002). Involvement of CB1 cannabinoid receptors in emotional behaviour. Psychopharmacology (Berl.) 159, 379-387.

Mascia, P., Pistis, M., Justinova, Z. Panlilio, L. V., Luchicchi, A., Lecca, S., Scherma, M., Fratta, W., Fadda, P., Barnes, C., Redhi, G. H., Yasar, S., Le Foll, B., Tanda, G., Piomelli, D., and Goldberg, S. R. (2011). Blockade of nicotine reward and reinstatement by activation of alpha-type peroxisome proliferator-activated receptors. Biol. Psychiatry 69, 633-641.

Mazzola, C., Medalie, J., Scherma, M., Panlilio, L. V., Solinas, M., Tanda, G., Drago, F., Cadet, J. L., Goldberg, S. R., and Yasar, S. (2009). Fatty acid amide hydrolase (FAAH) inhibition enhances memory acquisition through activation of PPAR-alpha nuclear receptors. Learn. Mem. 16, 332-337.

McLaughlin, R. J., Hill, M. N., Morrish, A. C., and Gorzalka, B. B. (2007). Local enhancement of cannabinoid CB1 receptor signalling in the dorsal hippocampus elicits an antidepressant-like effect. Behav. Pharmacol. 18, 431-438.

Melis, M., Carta, S., Fattore, L., Tolu, S., Yasar, S., Goldberg, S. R., Fratta, W., Maskos, U., and Pistis, M. (2010). Peroxisome proliferatoractivated receptors-alpha modulate dopamine cell activity through nicotinic receptors. Biol. Psychiatry 68, 256-264.

Micale, V., Cristino, L., Tamburella, A., Petrosino, S., Leggio, G. M., Drago, F., and Di Marzo, V. (2009). Anxiolytic effects in of a dual blocker of fatty acid amide hydrolase and transient receptor potential vanilloid type-1 channels. Neuropsychopharmacology 34, 593-606.

Mikics, E., Dombi, T., Barsvári, B., Varga, B., Ledent, C., Freund, T. F., and Haller, J. (2006). The effects of cannabinoids on contextual conditioned fear in CB1 knockout and CD1 mice. Behav. Pharmacol. 17, 223-230.

Mikics, E., Vas, J., Aliczki, M., Halasz, J., and Haller, J. (2009). Interactions between the anxiogenic effects of CB1 gene disruption and 5-HT3 neurotransmission. Behav. Pharmacol. 20, 265-272.

Millan, M. J. (2003). The neurobiology and control of anxious states. Prog. Neurobiol. 70, 83-244.

Mishima, K., Egashira, N., Hirosawa, N., Fujii, M., Matsumoto, Y., Iwasaki, K., and Fujiwara, M. (2001). Characteristics of learning and memory impairment induced by delta9tetrahydrocannabinol in rats. Jpn. J. Pharmacol. 87, 297-308.

Mishima, K., Egashira, N., Matsumoto, Y., Iwasaki, K., and Fujiwara, M. (2002). Involvement of reduced acetylcholine release in delta9tetrahydrocannabinol-induced impairment of spatial memory in the 8 -arm radial maze. Life Sci. 72, 397-407.

Moise, A. M., Eisenstein, S. A., Astarita, G., Piomelli, D., and Hohmann, A. G. (2008). An endocannabinoid signaling system modulates anxiety-like behavior in male Syrian hamsters. Psychopharmacology (Berl.) 200, 333-346.

Molina-Holgado, F., Molina-Holgado, E., Leret, M. L., González, M. I., and Reader, T. A. (1993). Distribution of indoleamines and $[3 \mathrm{H}]$ paroxetine binding in rat brain regions following acute or perinatal delta 9-tetrahydrocannabinol treatments. Neurochem. Res. 18, 1183-1191.

Moore, N. L. T., Greenleaf, A. L. R., Acheson, S. K., Wilson, W. A., Swartzwelder, H. S., and Kuhn, C. M. (2010). Role of cannabinoid receptor type 1 desensitization in greater tetrahydrocannabinol impairment of memory in adolescent rats. J. Pharmacol. Exp. Ther. 335, 294-301.

Mor, M., Rivara, S., Lodola, A., Plazzi, P. V., Tarzia, G., Duranti, A., Tontini, A., Piersanti, G., Kathuria, S., and 
Piomelli, D. (2004). Cyclohexylcarbamic acid $3^{\prime}$ - or $4^{\prime}$-substituted biphenyl-3-yl esters as fatty acid amide hydrolase inhibitors: synthesis, quantitative structure-activity relationships, and molecular modeling studies. J. Med. Chem. 47, 4998-5008.

Moreira, F. A., Grieb, M., and Lutz, B. (2009). Central side-effects of therapies based on CB1 cannabinoid receptor agonists and antagonists: focus on anxiety and depression. Best Prac. Res. Clin. Endocrinol. Metab. 23, 133-144.

Moreira, F. A., Kaiser, N., Monory, K., and Lutz, B. (2008). Reduced anxiety-like behaviour induced by genetic and pharmacological inhibition of the endocannabinoiddegrading enzyme fatty acid amide hydrolase (FAAH) is mediated by CB1 receptors. Neuropharmacology 54, 141-150.

Moreira, F. A., and Wotjak, C. T. (2010). Cannabinoids and anxiety. Curr. Top. Behav. Neurosci. 2, 429-450.

Morgese, M. G., Cassano, T., Gaetani, S., Macheda, T., Laconca, L., Dipasquale, P., Ferraro, L., Antonelli, T., Cuomo, V., and Giuffrida, A. (2009). Neurochemical changes in the striatum of dyskinetic rats after administration of the cannabinoid agonist WIN55,212-2. Neurochem. Int. 54, 56-64.

Murillo-Rodríguez, E., Giordano, M., Cabeza, R., Henriksen, S. J., Méndez Díaz, M., Navarro, L., and ProspéroGarcía, O. (2001). Oleamide modulates memory in rats. Neurosci. Lett. 313, 61-64.

Naderi, N., Haghparast, A., SaberTehrani, A., Rezaii, N., Alizadeh, A.-M., Khani, A., and Motamedi, F. (2008). Interaction between cannabinoid compounds and diazepam on anxiety-like behaviour of mice. Pharmacol. Biochem. Behav. 89, 64-75.

Naidu, P. S., Varvel, S. A., Ahn, K., Cravatt, B. F., Martin, B. R., and Lichtman, A. H. (2007). Evaluation of fatty acid amide hydrolase inhibition in murine models of emotionality. Psychopharmacology (Berl.) 192, 61-70.

Nakamura, E. M., da Silva, E. A., Concilio, G. V., Wilkinson, D. A., and Masur, J. (1991). Reversible effects of acute and long-term administration of delta-9-tetrahydrocannabinol (THC) on memory in the rat. Drug Alcohol Depend. 28, 167-175.

Nakazi, M., Bauer, U., Nickel, T., Kathmann, M., and Schlicker, E. (2000). Inhibition of serotonin release in the mouse brain via presynaptic cannabinoid CB1 receptors. Naunyn Schmiedebergs Arch. Pharmacol. 361, 19-24.

Nasehi, M., Piri, M., Jamali-Raeufy, N., and Zarrindast, M. R. (2010). Influence of intracerebral administration of NO agents in dorsal hippocampus (CA1) on cannabinoid statedependent memory in the stepdown passive avoidance test. Physiol. Behav. 100, 297-304.

Nava, F., Carta, G., Battasi, A. M., and Gessa, G. L. (2000). D dopamine receptors enable deltatetrahydrocannabinol induced memory impairment and reduction of hippocampal extracellular acetylcholine concentration. $\mathrm{Br}$. J. Pharmacol. 130, 1201-1210.

Nava, F., Carta, G., Colombo, G., and Gessa, G. L. (2001). Effects of chronic delta-tetrahydrocannabinol treatment on hippocampal extracellular acetylcholine concentration and alternation performance in the T-maze. Neuropharmacology 41, 392-399.

Niyuhire, F., Varvel, S. A., Thorpe, A. J., Stokes, R. J., Wiley, J. L., and Lichtman, A. H. (2007). The disruptive effects of the CB1 receptor antagonist rimonabant on extinction learning in are task-specific. Psychopharmacology (Berl.) 191, 223-231.

Pamplona, F. A., Bitencourt, R. M., and Takahashi, R. N. (2008). Short- and long-term effects of cannabinoids on the extinction of contextual fear memory in rats. Neurobiol. Learn. Mem. 90, 290-293.

Pamplona, F. A., Prediger, R. D., Pandolfo, P., and Takahashi R. N. (2006). The cannabinoid receptor agonist WIN 55,212-2 facilitates the extinction of contextual fear memory and spatial memory in rats. Psychopharmacology (Berl) 188, 641-649.

Pamplona, F. A., and Takahashi, R. N. (2006). WIN 55212-2 impairs contextual fear conditioning through the activation of CB1 cannabinoid receptors. Neurosci. Lett. 397, 88-92.

Panlilio, L. V., Yasar, S., Thorndike, E. B., Goldberg, S. R., and Schindler, C. W. (2011). Automatic recording of mediating behavior in delayed matching- and nonmatchingto-position procedures in rats. Psychopharmacology (Berl.) 214, 495-504.

Patel, S., and Hillard, C. J. (2006). Pharmacological evaluation of cannabinoid receptor ligands in a mouse model of anxiety: further evidence for an anxiolytic role for endogenous cannabinoid signaling. J. Pharmacol. Exp. Ther. 318, 304-311.

Phillips, R. G., and LeDoux, J. E. (1992). Differential contribution of amygdala and hippocampus to cued and contextual fear conditioning. Behav. Neurosci. 106, 274-285.

Piomelli, D., Tarzia, G., Duranti, A., Tontini, A., Mor, M., Compton, T. R., Dasse, O., Monaghan, E. P., Parrott, J. A., and Putman, D. (2006). Pharmacological profile of the selective FAAH inhibitor KDS4103 (URB597). CNS Drug Rev. 12, 21-38.

Quinn, H. R., Matsumoto, I., Callaghan, P. D., Long, L. E., Arnold, J. C., Gunasekaran, N., Thompson, M. R., Dawson, B., Mallet, P. E., Kashem, M. A., Matsuda-Matsumoto, H., Iwazaki, T., and McGregor, I. S. (2008). Adolescent rats find repeated delta-THC less aversive than adult rats but display greater residual cognitive deficits and changes in hippocampal protein expression following exposure. Neuropsychopharmacology 33, 1113-1126.

Quirk, G. J., and Mueller, D. (2008). Neural mechanisms of extinction learning and retrieval. Neuropsychopharmacology 33, 56-72.

Ranganathan, M., and D'Souza, D. C. (2006). The acute effects of cannabinoids on memory in humans: a review. Psychopharmacology (Berl.) 188, 425-444.

Realini, N., Vigano, D., Guidali, C., Zamberletti, E., Rubino, T., and Parolaro, D. (2011). Chronic URB597 treatment at adulthood reverted most depressive-like symptoms induced by adolescent exposure to THC in female rats. Neuropharmacology 60, 235-243.

Riedel, G., and Davies, S. N. (2005). Cannabinoid function in learning, memory and plasticity. Handb. Exp. Pharmacol. 168, 445-477.

Robinson, L., Goonawardena, A. V., Pertwee, R., Hampson, R. E., Platt, B., and Riedel, G. (2010). WIN55,212-2 induced deficits in spatial learning are mediated by cholinergic hypofunction. Behav. Brain Res. 208, 584-592.

Rodrigues, L. C., de, M., Conti, C. L., and Nakamura-Palacios, E. M. (2011). Clozapine and SCH 23390 prevent the spatial working memory disruption induced by $(\Delta$-THC administration into the medial prefrontal cortex. Brain Res. 1382, 230-237.

Rubino, T., Realini, N., Braida, D., Guidi, S., Capurro, V., Viganò, D., Guidali, C., Pinter, M., Sala, M., Bartesaghi, R., and Parolaro, D. (2009). Changes in hippocampal morphology and neuroplasticity induced by adolescent THC treatment are associated with cognitive impairment in adulthood. Hippocampus 19, 763-772.
Rubino, T., Realini, N., Castiglioni, C., Guidali, C., Viganó, D., Marras, E., Petrosino, S., Perletti, G., Maccarrone, M., Di Marzo, V., and Parolaro, D. (2008). Role in anxiety behavior of the endocannabinoid system in the prefrontal cortex. Cereb. Cortex 18, 1292-1301.

Scherma, M., Medalie, J., Fratta, W., Vadivel, S. K., Makriyannis, A., Piomelli, D., Mikics, E., Haller, J., Yasar, S., Tanda, G., and Goldberg, S. R. (2008). The endogenous cannabinoid anandamide has effects on motivation and anxiety that are revealed by fatty acid amide hydrolase (FAAH) inhibition. Neuropharmacology 54, 129-140.

Schneider, M., and Koch, M. (2002). The cannabinoid agonist WIN 55,2122 reduces sensorimotor gating and recognition memory in rats. Behav. Pharmacol. 13, 29-37.

Schneider, M., Schömig, E., and Leweke, F. M. (2008). PRECLINICAL STUDY: acute and chronic cannabinoid treatment differentially affects recognition memory and social behavior in pubertal and adult rats. Addict. Biol. 13, 345-357.

Seillier, A., and Giuffrida, A. (2011). Inhibition of fatty acid amide hydrolase modulates anxiety-like behavior in PCP-treated rats. Pharmacol. Biochem. Behav. 98, 583-586.

Silva de Melo, L. C., Cruz, A. P., Rios Valentim, S. J. Jr., Marinho, A. R. Mendonça, J. B., and NakamuraPalacios, E. M. (2005). Delta-THC administered into the medial prefrontal cortex disrupts the spatial working memory. Psychopharmacology (Berl.) 183, 54-64.

Sink, K. S., Segovia, K. N., Collins, L. E., Markus, E. J., Vemuri, V. K., Makriyannis, A., and Salamone, J. D. (2010). The CB1 inverse agonist AM251, but not the CB1 antagonist AM4113, enhances retention of contextual fear conditioning in rats. Pharmacol. Biochem. Behav. 95, 479-484.

Steiner, M. A., Marsicano, G., Nestler, E. J., Holsboer, F., Lutz, B., and Wotjak, C. T. (2008a). Antidepressant-like behavioral effects of impaired cannabinoid receptor type 1 signaling coincide with exaggerated corticosterone secretion in mice. Psychoneuroendocrinology 33, 54-67.

Steiner, M. A., Marsicano, G., Wotjak, C. T., and Lutz, B. (2008b). Conditional cannabinoid receptor type 1 mutants reveal neuron subpopulation-specific effects on behavioral and neuroendocrine stress responses. Psychoneuroendocrinology 33, 1165-1170. 
Straiker, A., and Mackie, K. (2009). Cannabinoid signaling in inhibitory autaptic hippocampal neurons. Neuroscience 163, 190-201.

Suenaga, T., and Ichitani, Y. (2008). Effects of hippocampal administration of a cannabinoid receptor agonist WIN 55,212-2 on spontaneous object and place recognition in rats. Behav. Brain Res. 190, 248-252.

Suenaga, T., Kaku, M., and Ichitani, Y. (2008). Effects of intrahippocampal cannabinoid receptor agonist and antagonist on radial maze and T-maze delayed alternation performance in rats. Pharmacol. Biochem. Behav. 91, 91-96.

Suzuki, A., Josselyn, S. A., Frankland, P. W., Masushige, S., Silva, A. J., and Kida, S. (2004). Memory reconsolidation and extinction have distinct temporal and biochemical signatures. J. Neurosci. 24, 4787-4795.

Tart, C. T. (1970). Marijuana intoxication common experiences. Nature 226, 701-704.

Tarzia, G., Duranti, A., Tontini, A., Piersanti, G., Mor, M., Rivara, S., Plazzi, P. V., Park, C., Kathuria, S., and Piomelli, D. (2003). Design, synthesis, and structure-activity relationships of alkylcarbamic acid aryl esters, a new class of fatty acid amide hydrolase inhibitors. J. Med. Chem. 46, 2352-2360.

Terranova, J. P., Storme, J. J., Lafon, N., Pério, A., Rinaldi-Carmona, M., Le Fur, G., Soubrié, P., and Umathe, S. N. (1996). Improvement of memory in rodents by the selective $\mathrm{CB} 1$ cannabinoid receptor antagonist, SR 141716. Psychopharmacology (Berl.) 126, 165-172.
Umathe, S. N., Manna, S. S., and Jain, N. S. (2011). Involvement of endocannabinoids in antidepressant and anti-compulsive effect of fluoxetine in mice. Behav. Brain Res. 223, 125134.

Urigüen, L., Pérez-Rial, S., Ledent, C., Palomo, T., and Manzanares, J. (2004). Impaired action of anxiolytic drugs in deficient in cannabinoid CB1 receptors. Neuropharmacology 46, 966-973.

Varvel, S. A., Anum, E. A., and Lichtman, A. H. (2005a). Disruption of $\mathrm{CB} 1$ receptor signaling impairs extinction of spatial memory in mice. Psychopharmacology (Berl.) 179, 863-872.

Varvel, S. A., Anum, E., Niyuhire, F., Wise, L. E., and Lichtman, A. H. (2005b). Delta-THC-induced cognitive deficits in are reversed by the GABA(A) antagonist bicuculline. Psychopharmacology (Berl.) 178, 317-327.

Varvel, S. A., Cravatt, B. F., Engram, A. E., and Lichtman, A. H. (2006). Fatty acid amide hydrolase (-/-) exhibit an increased sensitivity to the disruptive effects of anandamide or oleamide in a working memory water maze task. J. Pharmacol. Exp. Ther. 317, 251-257.

Varvel, S. A., Hamm, R. J., Martin, B. R., and Lichtman, A. H. (2001). Differential effects of delta 9-THC on spatial reference and working memory in mice. Psychopharmacology (Berl.) 157, 142-150.

Varvel, S. A., and Lichtman, A. H. (2002). Evaluation of CB1 receptor knockout in the Morris water maze. J. Pharmacol. Exp. Ther. 301, 915-924.
Varvel, S. A., Wise, L. E., and Lichtman, A. H. (2009). Are CB1 receptor antagonists nootropic or cognitive impairing agents? Drug Dev. Res. 70, 555-565.

Varvel, S. A., Wise, L. E., Niyuhire, F., Cravatt, B. F., and Lichtman, A. H. (2007). Inhibition of fatty-acid amide hydrolase accelerates acquisition and extinction rates in a spatial memory task. Neuropsychopharmacology 32, 1032-1041.

Walker, J. M., Huang, S. M., Strangman, N. M., Tsou, K., and Sañudo-Peña, M. C. (1999). Pain modulation by release of the endogenous cannabinoid anandamide. Proc. Natl. Acad. Sci. U.S.A. 96, 12198-12203.

Wilson, R. I., and Nicoll, R. A. (2001). Endogenous cannabinoids mediate retrograde signalling at hippocampal synapses. Nature 410, 588-592.

Wise, L. E., Harloe, J. P., and Lichtman, A. H. (2009a). Fatty acid amide hydrolase (FAAH) knockout exhibit enhanced acquisition of an aversive, but not of an appetitive, Barnes maze task. Neurobiol. Learn. Mem. 92, 597-601.

Wise, L. E., Thorpe, A. J., and Lichtman, A. H. (2009b). Hippocampal $\mathrm{CB} 1$ receptors mediate the memory impairing effects of delta-tetrahydrocannabinol. Neuropsychopharmacology 34,2072-2080.

Wise, L. E., Iredale, P. A., and Lichtman, A. H. (2008). The cannabinoid $\mathrm{CB} 1$ receptor antagonist $\mathrm{CE}$ prolongs spatial memory duration in a rat delayed radial arm maze memory task. Eur. J. Pharmacol. 590, 246-249.

Wise, L. E., Iredale, P. A., Stokes, R. J., and Lichtman, A. H. (2007).
Combination of rimonabant and donepezil prolongs spatial memory duration. Neuropsychopharmacology 32, 1805-1812.

Wolff, M. C., and Leander, J. D. (2003). SR141716A, a cannabinoid CB1 receptor antagonist, improves memory in a delayed radial maze task. Eur. J. Pharmacol. 477, 213-217.

Wright, L. K. M., Liu, J., Nallapaneni, A., and Pope, C. N. (2010). Behavioral sequelae following acute diisopropylfluorophosphate intoxication in rats: comparative effects of atropine and cannabinomimetics. Neurotoxicol. Teratol. 32, 329-335

Conflict of Interest Statement: The authors declare that the research was conducted in the absence of any commercial or financial relationships that could be construed as a potential conflict of interest.

Received: 07 July 2011; paper pending published: 22 July 2011; accepted: 21 August 2011; published online: 13 September 2011.

Citation: Zanettini C, Panlilio LV, Aliczki $M$, Goldberg SR, Haller $J$ and Yasar S (2011) Effects of endocannabinoid system modulation on cognitive and emotional behavior. Front. Behav. Neurosci. 5:57. doi: 10.3389/fnbeh.2011.00057

Copyright (c) 2011 Zanettini, Panlilio, Aliczki, Goldberg, Haller and Yasar. This is an open-access article subject to a nonexclusive license between the authors and Frontiers Media SA, which permits use, distribution and reproduction in other forums, provided the original authors and source are credited and other Frontiers conditions are complied with. 